\title{
新構造材料適用省エネ型エ作機械の熱変位および省エネルギ一性能評価
}

\author{
加藤 慎 ${ }^{* 1}$, 河野 大輔 ${ }^{* 2}$, 吉岡 勇人*3, 杉田 直彦*4, 浜口 顕秀*5, 高野 和雅*6 \\ 飯島 一憲*7, 柿沼 康弘 ${ }^{* 8}$
}

\section{Thermal error and energy-saving performance evaluation of the energy-saving machine tool using new structural materials}

\author{
Makoto KATO*1 ${ }^{*}$, Daisuke KONO ${ }^{* 2}$, Hayato YOSHIOKA ${ }^{* 3}$, Naohiko SUGITA ${ }^{* 4}$, \\ Akihide HAMAGUCHI ${ }^{* 5}$, Kazumasa $\mathrm{KONO}^{* 6}$, Kazunori IIJIMA ${ }^{* 7}$ and Yasuhiro KAKINUMA ${ }^{* 8}$ \\ ${ }^{* 1,{ }^{*}}$ School of Integrated Design Engineering, Keio University, 3-14-1 Hiyoshi, Kohoku-ku, Yokohama 223-8522, Japan \\ ${ }^{*}$ Department of Micro Engineering, Graduate School of Engineering, Kyoto University, C3 Kyotodaigaku Katsura, Nisikyo-ku, Kyoto 615-8540, Japan \\ ${ }^{* 3}$ Institute of Innovative Research, Tokyo Institute of Technology, 4259 Nagatsuta, Midori-ku, Yokohama 226-8503, Japan \\ ${ }^{*}$ Department of Mechanical Engineering, School of Engineering, The University of Tokyo, 7-3-1 Hongo, Bunkyo-ku, Tokyo 113-8656, Japan \\ ${ }^{*}$ Research \& Development, OKUMA Corporation, 5-25-1 shimooguchi, Oguchi-cho, Niwa-gun, Aichi 480-0193, Japan \\ ${ }^{* 6}$ Research \& Development, Makino Milling Machine Corporation, 4023 Nakatsu, Aikawa-cho, Aiko-gun, Kanagawa 243-0303, Japan \\ ${ }^{* 7}$ Servo Laboratory, FANUC Corporation, 3580 Shibokusa, Oshino-mura, Minamitsuru-gun, Yamanashi 401-0597, Japan
}

Received: 23 December 2019; Revised: 7 February 2020; Accepted: 3 March 2020

\begin{abstract}
New energy saving methods are required to address global climate change and resource depletion. New structural materials such as Carbon fiber reinforced plastic (CFRP) are used also in nowadays machine tools applications for energy efficiency improvement by weight reduction. This research group succeed in being the first to develop the energy-saving machine tool using new structural materials, mainly CFRP. Furthermore, CFRP is expected to enhance thermal characteristics, which contributes to reduction of warm up drive and implement of idle reduction. First of all, the thermal deformation of the energysaving machine tool is investigated through single axis feed motion by measuring a test bar. It is obtained that the thermal error is obviously suppressed and shows unique behavior in comparison with a based conventional machine tool. Next, the energysaving performance is evaluated through machining test. Warm up drive minimization method is proposed in order to realize high precision form accuracy. The warm up drive time is estimated based on an estimation model, and the energy efficiency of warm up drive is improved $57.0 \%$ in comparison with the base machine.
\end{abstract}

Keywords : Accuracy, Machine tool, Thermal deformation, Environmental benign manufacturing, Warm up drive

\section{1. 緒言}

環境と限りある資源を守るための重要な課題として，温室効果ガスの排出量削減技術に世界中で注目が集まっ ている．気候変動枠組条約締約国会議（COP）が毎年開催されており，2015 年のCOP21 では全 196 力国が参加

No.20-00002 [DOI:10.1299/transjsme.20-00002], J-STAGE Advance Publication date : 12 March, 2020

*1 慶應義塾大学大学院 理工学研究科 総合デザイン工学専攻（テ223-8522 神奈川県横浜市港北区日吉 3-14-1)

*2 正員, 京都大学 工学研究科 マイクロエンジニアリング専攻（† 615-8540 京都府京都市西京区京都大学桂 C3）

*3 正員，東京工業大学 科学技術創成研究院（干226-8503＼cjkstart神奈川県横浜市緑区長津田町 4259）

*4 正員, 東京大学 工学系研究科 機械工学専攻（广113-8654 東京都文京区本郷 7-3-1)

*5 オークマ (株) 研究開発部 要素開発課（广480-0193 愛知県丹羽郡大口町下小口 5-25-1）

*6 正員，（株）牧野フライス製作所 先行開発部（テ243-0303＼cjkstart神奈川県愛甲郡愛川町中津 4023）

*7 ファナック (株) FA 事業本部 サーボ研究所（厂401-0597 山梨県南都留郡忍野村忍草 3580)

*8 正員, 慶應義塾大学 理工学部 システムデザイン工学科

E-mail of corresponding author: kato@ams.sd.keio.ac.jp 
Kato, Daisuke Kono, Yoshioka, Sugita, Hamaguchi, Kazumasa Kono, Iijima and Kakinuma, Transactions of the JSME (in Japanese), Vol.86, No.884 (2020)

するパリ協定が採択された．現在日本では全エネルギー需要の $40 \%$ 以上が産業分野， $20 \%$ 以上が運輸分野で消費 されている(経済産業省資源エネルギー庁, 2018). 産業分野のエネルギー消費原単位の推移は横ばいであり, e ב マースの普及による運輸分野でのエネルギー消費桩大を受け，2018 年 6 月に省エネ法が改正されるなど対応が図 られている．また，エネルギー効率の向上と再生可能エネルギーの普及のために先進国が電気自動車への完全移 行を次々に発表しており,今後も機械加工を行う工作機械の需要の変化が見込まれる.工場全体の消費電力の $50 \%$ 以上を占める工作機械における省エネルギー化技術は，環境性能の向上だけでなく低コスト化により製造業者に 経済的利益も与えることができる.

工作機械の省エネルギー化技術は, 周辺機器のインバータ化や ATC の利用など, 自動化を伴いながら発展して きた. 消費電力の分析によると, 除去加工そのものに必要な電力を除いた, 冷却機構やサーボアンプといった周 辺機器の消費電力が 5 軸加工機の消費電力の $75 \%$ を占めている(Altıntaş et al., 2016). そこで, エネルギー効率の 向上及び稼働時間の削減により省エネルギー化が進められている．例えば，加工工程に合わせた切削液流量の制 御(Fujishima et al., 2017), ベッドの冷却機構の制御(Regel et al., 2018), 主軸の冷却機構の解析(Weber et al., 2018)に より最適化が図られてきた．また，待機中の搬送機器の停止(Fujishima et al., 2017)や複数の工程を集約可能な工作 機械の開発(Ohtani et al., 2017)など，不要な電力消費を避ける方法が検討されている．加工においては，送り速度 の高速化が可能な工具の開発(Ullah et al., 2016)や，切削力を基準とした主軸回転数と送り速度の最適化(Lee et al., 2017)で材料除去率を向上寸ることで周辺装置の稼働時間を削減している。

大幅な省エネルギー化を達成するためには，工作機械を構造から見直すことで機械特性を高める必要がある. 炭素䋊維強化プラスチック（CFRP）は軽量のみならず，工作機械に必要とされる高い岡性と減衰性，低熱膨張率 を有しており，駆動部の軽量化と加工の高能率化に貢献する材料として注目を集めている(Möhring et al., 2015). 構成要素や小型工作機械一 CFRP を部分的に適用する試みは既に始まっており，レジンコンクリート（REC）と 併用することで岡性，減衰性，熱特性の向上が期待されているが，CFRP などの新構造材料をあらゆる要素に採 用した工作機械の開発ならびに評価は未だ行われていない.

日本工作機械工業会では，加工システム研究開発機構において，工作機械の主要構造および主要要素すべてに CFRP を適用した省エネ型工作機械を初めて作製した（図 1)。新構造材料の剛性と減衰性は加工時間の短縮に寄 与し，熱特性は暖機運転時間の削減とアイドリングストップの採用に貢献する(杉田他, 2019). 機械の熱変形の影 響は工作物の幾何誤差の要因の 75\%以上にあたると言われ(Mayr et al., 2012), 製造の場面では許容する誤差範囲 に加工中の変位が収まるように暖機運転が行われる．暖機運転中の消費エネルギーに関して，熱的に安定な材料 一置き換えることで暖機運転が短縮可能となり大幅なエネルギー削減が見込める．また，多品種の生産を担う近 年の工作機械では，段取りなどの違いにより加工部品ごとに異なる待機時間が生じており，高精度加工を実現す る上で長時間の稼働を見据えた熱変位の特定は必要不可欠となる.

そこで本研究グループでは, 開発した省エネ型工作機械とベース機の比較実験を通して, 熱変位と省エネルギ 一性能評価を行った，始めに，主軸や送り系を動作させた場合に生じる主軸先端点の熱変位を評価した．次に， 暖機運転の有無と非等間隔な待機時間が加工精度に与える影響を評価した．この加工試験では，工作物の加工形 状を測定することで，加工中に変化する熱変位を特定した．加工試験の結果より加工精度の維持に必要な暖機運 転時間を算出し，比較することで CFRP 適用の有用性を示した. 6 つの工作物を加工するモデルケースにおいて， 精度維持に必要な暖機運転にかかる消費エネルギーを $57.0 \%$ 削減することに成功した. 加えて, 熱変位モデルを 利用した，暖機運転時間を短縮する省エネルギー加工を提案した.

\section{2. 新構造材料を適用した工作機械の熱変位の測定}

\section{$2 \cdot 1$ 新構造材料適用省エネ型工作機械}

図 1 に示した開発機は小型 5 軸加工機（MILLAC33TU，オークマ）をモデルにしており，各要素の形状に関し ては同様の設計を行っている. 構造コードで表すと[CA/YXZ]である. 図中では取り外しているが，機体を覆うカ バーにはアルミニウム合金の骨組みとアクリル板を使用した．表 1 には，ベース機と開発機の各移動・旋回軸の 慣性を示しており，CFRP を構造材料へ適用したことにより大幅な軽量化を達成した．また，表 2 にはモータ出 カと送り軸のストロークを示した. 
Kato, Daisuke Kono, Yoshioka, Sugita, Hamaguchi, Kazumasa Kono, Iijima and Kakinuma, Transactions of the JSME (in Japanese), Vol.86, No.884 (2020)

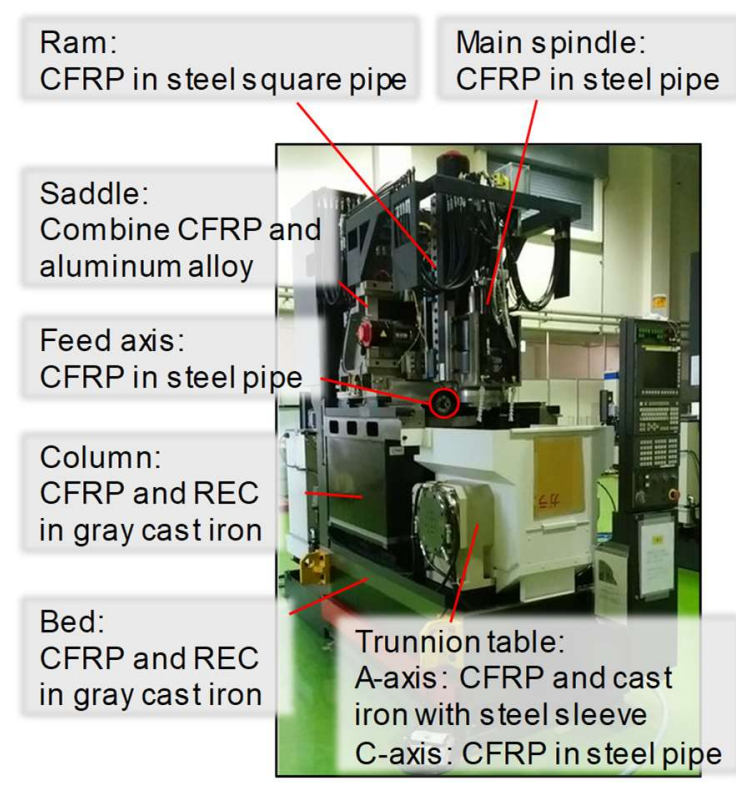

Fig. 1 Prototype machine using new structural materials.
Table 1 Structures load.

\begin{tabular}{c|c|c}
\hline \hline Machine type & Base machine & Prototype machine \\
\hline X-axis mass & $950 \mathrm{~kg}$ & $710 \mathrm{~kg}$ \\
\hline Y-axis mass & $2050 \mathrm{~kg}$ & $1190 \mathrm{~kg}$ \\
\hline Z-axis mass & $600 \mathrm{~kg}$ & $490 \mathrm{~kg}$ \\
\hline A-axis inertia & $2.8 \mathrm{kgm}^{2}$ & $1.9 \mathrm{kgm}^{2}$ \\
\hline C-axis inertia & $0.22 \mathrm{kgm}^{2}$ & $0.15 \mathrm{kgm}^{2}$ \\
\hline
\end{tabular}

Table 2 Motor specifications.

\begin{tabular}{c|c|c}
\hline \hline Axis & Travel & Rated power \\
\hline X feed & $340 \mathrm{~mm}$ & $2.5 \mathrm{~kW}$ \\
\hline Y feed & $300 \mathrm{~mm}$ & $2.7 \mathrm{~kW}$ \\
\hline Z feed & $230 \mathrm{~mm}$ & $4.5 \mathrm{~kW}$ \\
\hline A rotation & - & $2.4 \mathrm{~kW}$ \\
\hline C rotation & - & $3.7 \mathrm{~kW}$ \\
\hline Spindle rotation & - & $26 \mathrm{~kW}$ \\
\hline
\end{tabular}

熱変位の測定に際して，始めにCFRP を適用した構成要素毎の熱変形の評価を行った. 主軸シャフトは軸受や ホルダとの接触と摺動から CFRP を保護するため, 鋼スリーブで覆われている．主軸ユニットを $12000 \mathrm{~min}^{-1}$ で回 転させた場合の回転軸方向の熱変位を 70\%低減した(Kono et al., 2019). ラムは圧延鋼パイプ内に CFRP を配置す ることにより対称的な構造を維持し，同じ温度変化環境において送り軸方向の熱変位を $30 \%$ 低減した(杉田他， 2019). サドル・スライダはアルミニウム合金鋳物と CFRP で構成されており，送り軸の発熱に対して熱変位を 30\%低減した(杉田他, 2019). コラム・ベッドは固定体であるため, ねずみ鋳鉄に加えて減衰性の高い REC を CFRP と複合させることにより更なる静剛性・減衰比の向上を達成した. 熱特性の劣る REC を有限要素法により決定し た適正な充填率・配置で使用寸ることで，Z 軸方向熱変位を 20\%低減した(杉田他, 2019). 直線送り軸と C 軸旋回 軸には CFRP パイプを組み込み，A 軸旋回軸には回転中心から離れた構造部に CFRP を適用することで低慣性モ ーメント化を図った２時間のモータ駆動で生じる熱変位を 50\%低減した(加藤他, 2018). 以上のようにCFRPを 適用した各機械要素は, 熱特性が向上することを確認した. 機械加工を行う上では, これらの要素を統合した工 作機械において，工具-工作物間に生じる熱変位の評価を行うことが必要となる.

\section{$2 \cdot 2$ 駆動で生じる熱変位の測定実験}

CFRP は, 配向を揃えた炭素繊維を樹脂で覆ったプリプレグと呼ばれるシートを重ねて積層することで, 製造 される．プリプレグの炭素繊維配向を調整することで, 機械的特性を自由に設計できる一方で熱特性の異方性が 生じる. そこで各駆動軸から生じる熱が工具-工作物間の変位に与える影響を評価するために, 単一駆動軸のみを 連続運転して, 駆動時と待機時に生じる熱変位を測定した。本研究では, 工作機械において最大の発熱源である 主軸付近の影響を評価するため, $\mathrm{Z}$ 軸の送り駆動と主軸回転動作により生じる熱変位を調べた．図 2 に熱変位測 定実験の外観および構成を示す.工作物台となる $\mathrm{C}$ 軸テーブル上に固定したジグには計 6 個の静電容量変位計

（分解能 $0.010 \mu \mathrm{m}$ ）を設置した. 6 つの変位計により, 主軸頭つばの変位, テストバーの X・Y・Z 軸方向に生じ た変位，テストバーの傾きを測定することができる．変位計で測定された相対変位は，アンプを介してデータロ ガーにて 4 秒間隔で取得した。同様に主軸頭先端部の温度・温調器からの冷却液出入口の温度・室温を測定寸る ため, 熱電対を取り付けた. 表 3 および表 4 に Z 軸駆動および主軸回転動作の熱変位測定における実験条件を示 す.

$\mathrm{Z}$ 軸送り動作の試験においては, 測定用ジグから X 方向に一度逃がしてから $20 \mathrm{~mm}$ の往復運動を 9 回, $110 \mathrm{~mm}$ の往復運動を 1 回行った後に, 測定点へ戻り変位計測を行う動作を繰り返し実施した. 3 時間この動作を繰り返 
Kato, Daisuke Kono, Yoshioka, Sugita, Hamaguchi, Kazumasa Kono, Iijima and Kakinuma, Transactions of the JSME (in Japanese), Vol.86, No.884 (2020)

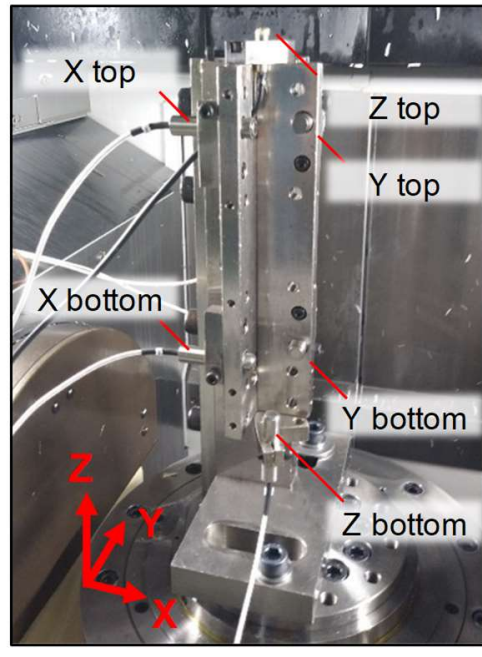

(a) Measure test bar on base machine

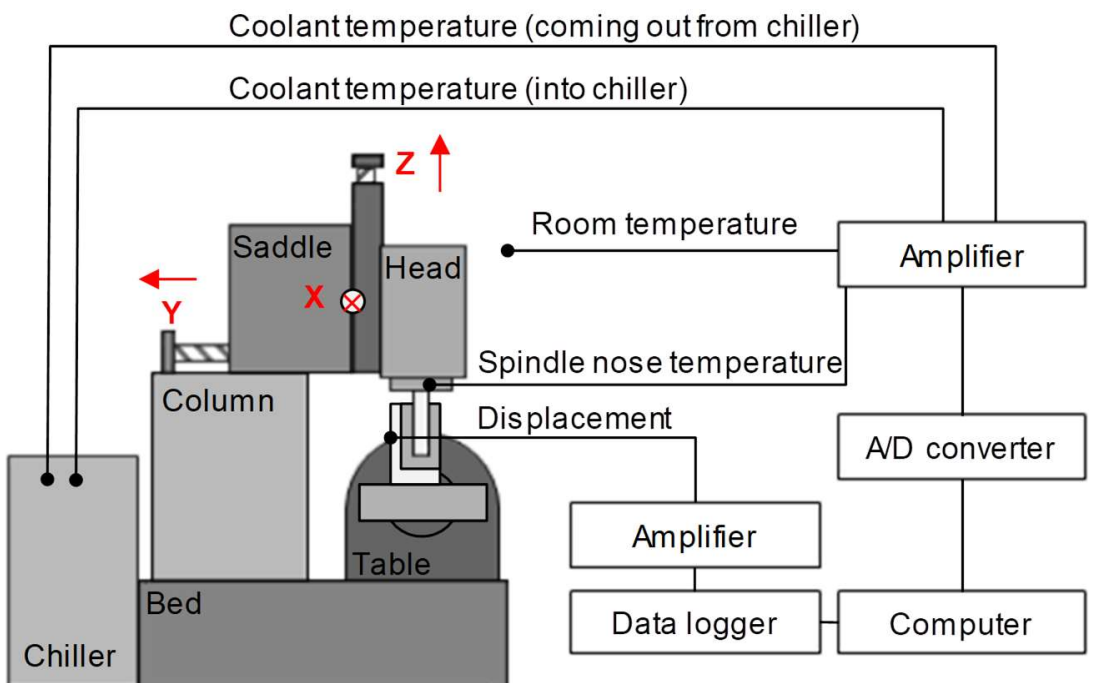

(b) Schematic diagram of measurement system and mechanical configuration

Fig. 2 Experimental setup for measuring thermal displacement and temperatures.

Table 3 Experimental conditions of $\mathrm{Z}$ axis motion.

\begin{tabular}{c|c}
\hline \hline Feed rate & $10 \mathrm{~m} / \mathrm{min}$ \\
\hline One cycle of feed length & $20 \mathrm{~mm} \times 9,110 \mathrm{~mm} \times 1$ \\
\hline Operating time & 3 hours \\
\hline Coolant unit at setup & On \\
\hline
\end{tabular}

Table 4 Experimental conditions of spindle rotation.

\begin{tabular}{c|c}
\hline \hline Spindle speed & $12000 \mathrm{~min}^{-1}$ \\
\hline Operating time & 2 hours \\
\hline Coolant unit at setup & On / Off \\
\hline
\end{tabular}

した後，Z 軸の動作を停止し，テストバーの変位を引き続き計測した。ベース機・開発機どちらにおいても，主 軸のジャケット冷却のための冷却装置を有しているが，本計測では，冷却装置は稼働したままとした。

主軸回転動作では，回転指令 $12000 \mathrm{~min}^{-1}$ で 2 時間運転し，停止後は待機状態とアイドリングストップの 2 条件 で測定を行った。ここでアイドリングストップとは，冷却装置を停止して待機している状態と定義する．また， 実験では開発機のみサーモグラフィでの主軸頭の温度測定を行った。

\section{2-3 CFRP 適用によって変化した熱特性の考察}

\section{2・3・1 Z 軸送り動作で生じる熱変位}

図 3 に Z 軸駆動によって主軸頭つば-テーブル間に生じた熱変位を示す. X 軸方向の熱変位は, 正面から見て左 右対称に設計された工作機械であるため小さいが，開発機では CFRP 適用の効果により $1 \mu \mathrm{m}$ 以上の変位が生じ なかった．ベース機で生じた Z 軸変位では，運動開始から 10 分程度で負方向に約 $6.5 \mu \mathrm{m}$ の急激な変位が生じ， その後は正方向の変位によって，運動停止までにほぼ初期位置に戻っている．運動開始直後の急激な変位は，ボ 一ルねじと案内の摩擦熱によるラム（Z 軸移動体）の急激な温度上昇により，ラムにおけるナットより下部が Z 方向に膨張したことが原因と考えられる，その後は運動を継続することで，モータ・ボールねじ・案内の熱が Z 軸のベースに伝達される．このため， Z 軸ベースの熱膨張による正方向の熱変位が生じ，負方向の熱変位がキャ ンセルされたと考えられる. 一方で開発機ではガラスエンコーダを採用したことに加え, 後述するように送り軸 とラムに CFRP を適用したことで温度が上がりにくく，Z 軸方向の変位が抑制されている. 3 時間の運転で生じ た Y 軸方向の変位は, ベース機で $15.2 \mu \mathrm{m}$, 開発機で $10.6 \mu \mathrm{m}$ と $30.2 \%$ 減少した. 低熱膨張率を有する CFRP の適 用により，駆動によって生じる送り軸方向以外の熱変位も抑制されることを確認した.

図 4 は上下の変位計から取得した相対変位の差から算出したテストバーの A 軸方向と B 軸方向の傾きである. Z 軸方向の駆動では B 軸の傾きは十分に小さいが, A 軸の傾きは $200 \mathrm{~mm}$ あたりベース機で $2.0 \mu \mathrm{m}$, 開発機で 
Kato, Daisuke Kono, Yoshioka, Sugita, Hamaguchi, Kazumasa Kono, Iijima and Kakinuma, Transactions of the JSME (in Japanese), Vol.86, No.884 (2020)

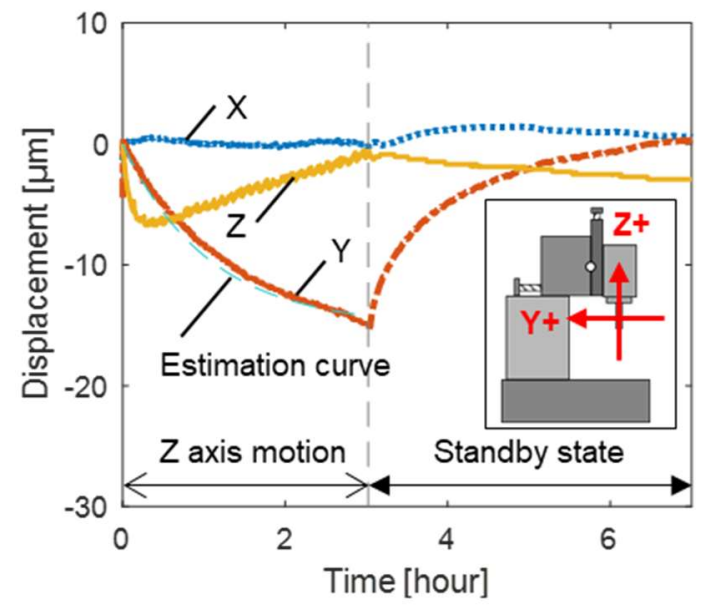

(a) Base machine

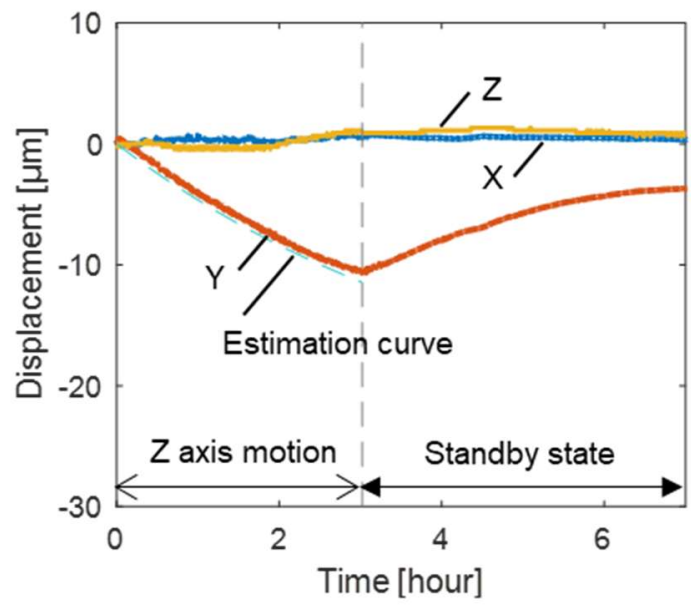

(b) Prototype machine

Fig. 3 Experimental results of thermal displacement on $Z$ axis motion.

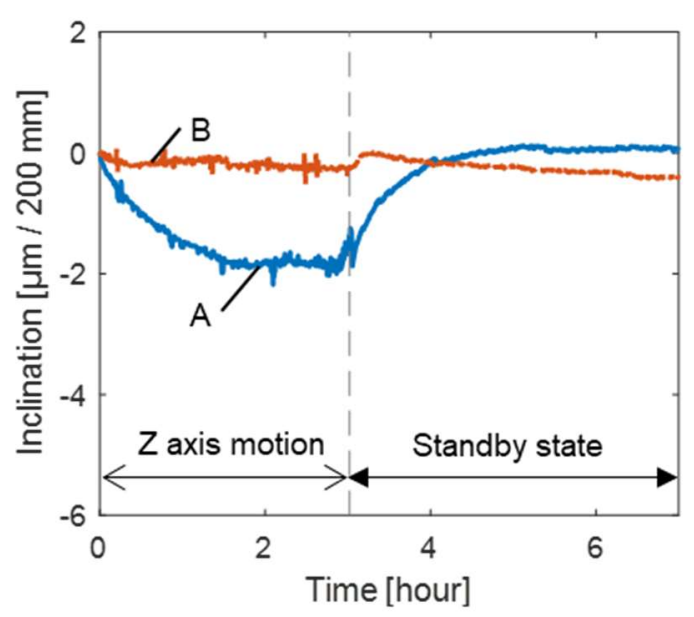

(a) Base machine

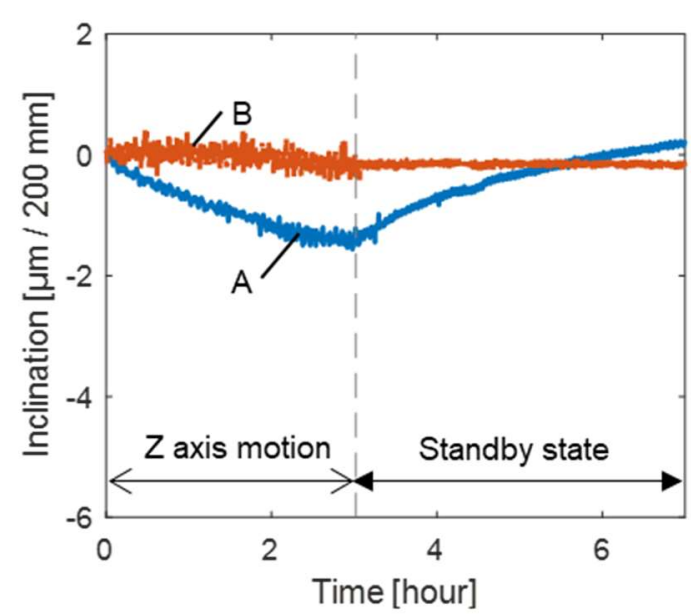

(b) Prototype machine

Fig. 4 Experimental results of inclination on $\mathrm{Z}$ axis motion.

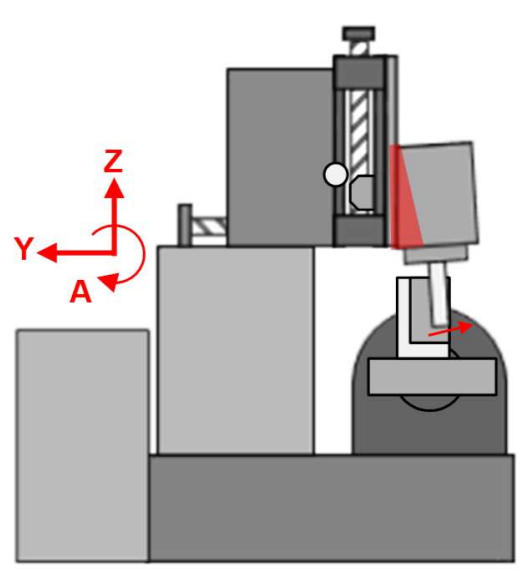

- Frictional heat released to ram and spindle head.

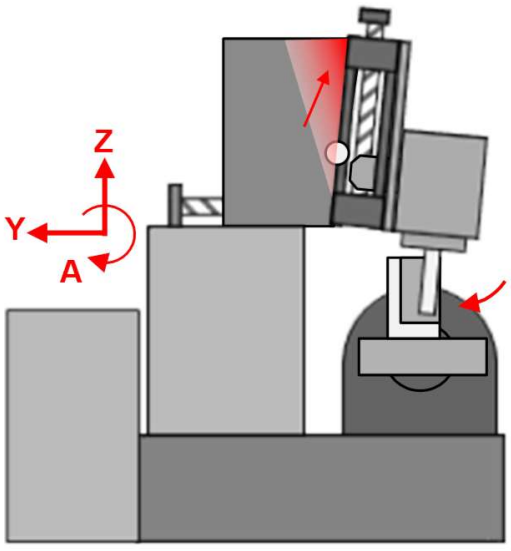

- Spindle head graduallygets cold.

- Saddle gets wam by thermal conduction from motor and sliding surface.

- Ram keeps its dimensions on $Z$ axis direction

(a) In the beginning of $Z$ axis motion

(b) In standby state

Fig. 5 Discussion of thermal deformation on $\mathrm{Z}$ feed drive. 
Kato, Daisuke Kono, Yoshioka, Sugita, Hamaguchi, Kazumasa Kono, Iijima and Kakinuma,

Transactions of the JSME (in Japanese), Vol.86, No.884 (2020)

$1.6 \mu \mathrm{m}$ 生じた．開発機では CFRP の適用により，主軸頭が上部に持ち上がるような変形が抑制されている. しか し, 傾きの変化の立ち上がりが遅く, 待機状態では初期の傾き以上に戻り逆方向への傾きが生じている. 図 5 の 模式図に示すように，駆動中は駆動範囲のボールねじと摺動面において摩擦熱が発生する. 今回の駆動範囲はス トロークの下端付近であるため, 主軸頭の上部と比較して下部の温度が高くなることで Y 方向に大きく膨張す る.ベース機と同様に, この膨張によってテストバーには A 軸負方向の傾きが生じる. そして待機状態になると, 主軸頭は冷却されて温度が低下寸るが，Z 軸上端に位置するモータの熱が Z 軸ベースへ伝達されてくる. ベース 機の場合は Z 軸ベースの緩やかな膨張が確認されたが，開発機では送り軸方向に対して熱変位量の小さいボール ねじがダブルアンカで取り付けられているため屈みこむような変形が生じた．このため，テストバーにはY 軸方 向の変位と $\mathrm{A}$ 軸正方向の傾きが残ったと考えられる. 本試験ではサドルや主軸頭上部の温度測定は行っていない ため, 今後も温度測定に基づいた熱変形の検証を行うことが必要といえる.

\section{$2 \cdot 3 \cdot 2$ 主軸回転動作で生じる熱変位}

図 6 に主軸回転動作後にアイドリングストップを行った際の主軸-テーブル間の熱変位を示す. 振れ回りによる 変位の影響を除去するため, 回転周期に相当するサンプル点数 (50 サンプル) で移動平均をとることでフィルタ

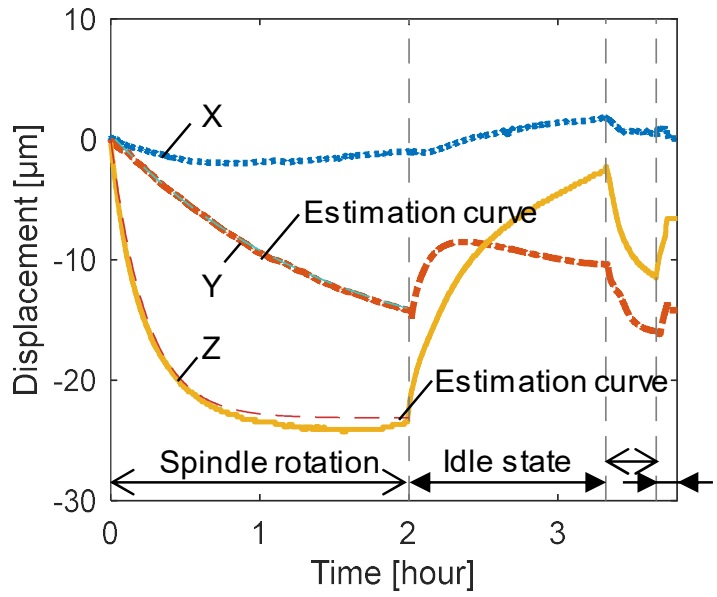

(a) Base machine

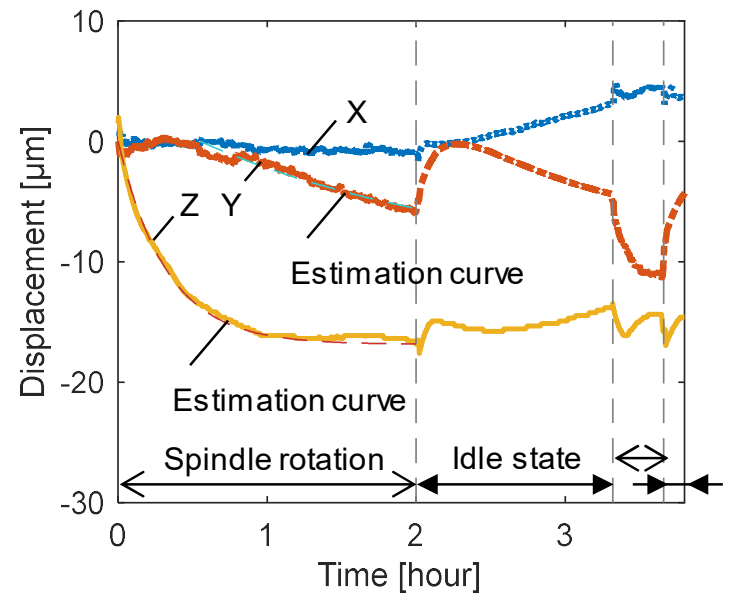

(b) Prototype machine

Fig. 6 Experimental results of thermal displacement on spindle rotation in idle state.

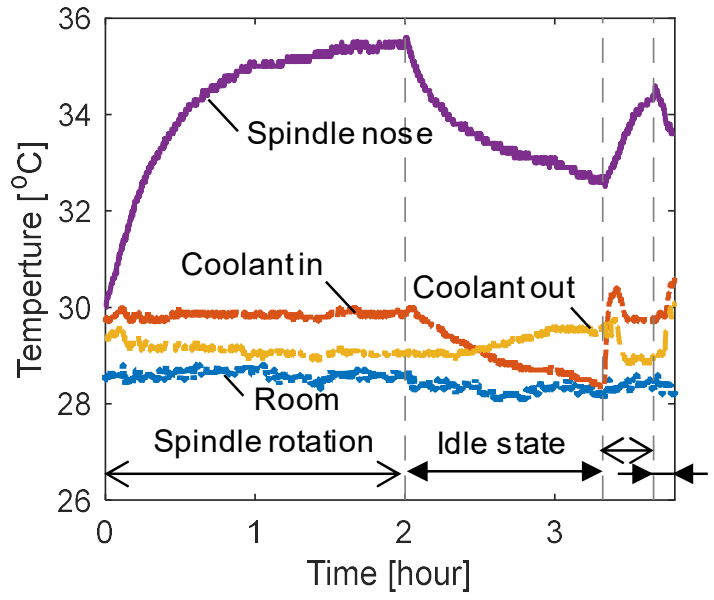

(a) Base machine

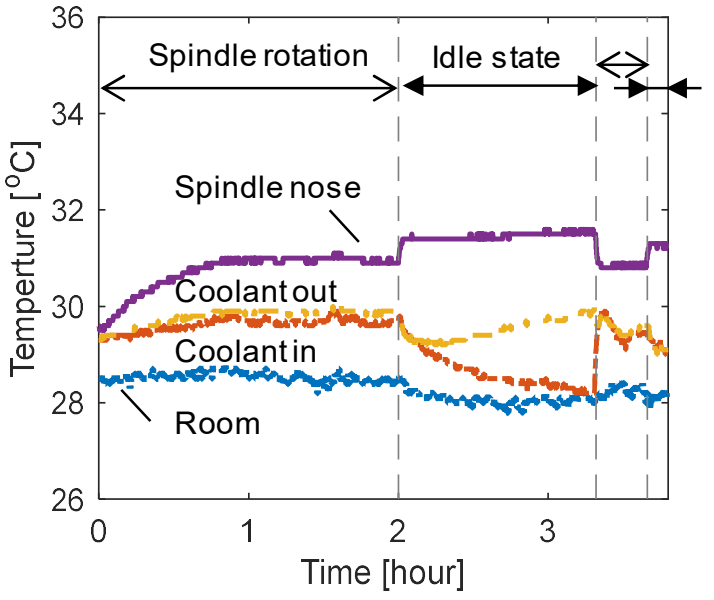

(b) Prototype machine

Fig. 7 Temperature measurements on spindle rotation in idle state. 
Kato, Daisuke Kono, Yoshioka, Sugita, Hamaguchi, Kazumasa Kono, Iijima and Kakinuma,

Transactions of the JSME (in Japanese), Vol.86, No.884 (2020)

リングしている．2 時間の主軸回転動作で生じた X 軸方向の熱変位は小さい．Y 軸方向の変位はベース機で 14.3 $\mu \mathrm{m}$, 開発機で $6.3 \mu \mathrm{m}$ と $55.9 \%$ 低減した. 各軸方向で比較して最も主軸発熱の影響を受けた Z 軸方向の熱変位は, ベース機で $24.1 \mu \mathrm{m}$, 開発機で $18.2 \mu \mathrm{m}$ と $24.5 \%$ 低減した. ここで開発機では，アイドリングストップを行うこと で Z 軸方向の変位が $2 \mu \mathrm{m}$ 程度変化した後に一定となる，特徴的な応答が確認できる．図 7 には熱電対による温 度測定の結果を示す．開発機では，回転停止直後に温度が 1 度上昇し，停止中はほぼ一定の温度を保っている. この原因は以下のように考察される。一般的な鋼主軸では，回転停止後に主軸頭に伝達される熱量が主軸頭にお ける外気への放熱量よりも少ないため，図 7 (a)に示すように，時間とともに主軸頭の温度は低下寸る．これに対 して，開発機の主軸では以下の違いがあると考察した。

・図 7 に示すように, ベース機よりも主軸頭の温度が低く, 主軸頭における外気への放熱量が少ない.

・ CFRP を使用したことにより，主軸シャフトの半径方向の熱伝導性が低い。このため, ベース機と比較

して，フロントベアリング付近の熱がシャフトよりもハウジングと主軸頭により多く伝達される.

上記 $2 つ$ 要因によって, 主軸頭における入熱量と放熱量がバランスしたために, 主軸頭が一定の温度を保って いると推測される.

図 8 に主軸回転動作によって生じたテストバーの傾きを示寸.ベース機では $200 \mathrm{~mm}$ あたり Y 軸方向に $5.0 \mu \mathrm{m}$ の傾きが生じており, 開発機の主軸回転に伴い生じる傾きについては正確な評価結果を得ることができなかった. しかし待機時に生じる A 軸の傾きは, ベース機の場合, 熱伝導により放熱されることで初期の傾きへ戻る様子が 確認できたが，開発機では傾きが収まらずに増加し続けている．この傾きに起因する Y 軸方向の変位は，加工時 の形状精度を悪化させる要因になると考えられる。図 7 では，開発機では主軸回転による発熱に対して温度上昇

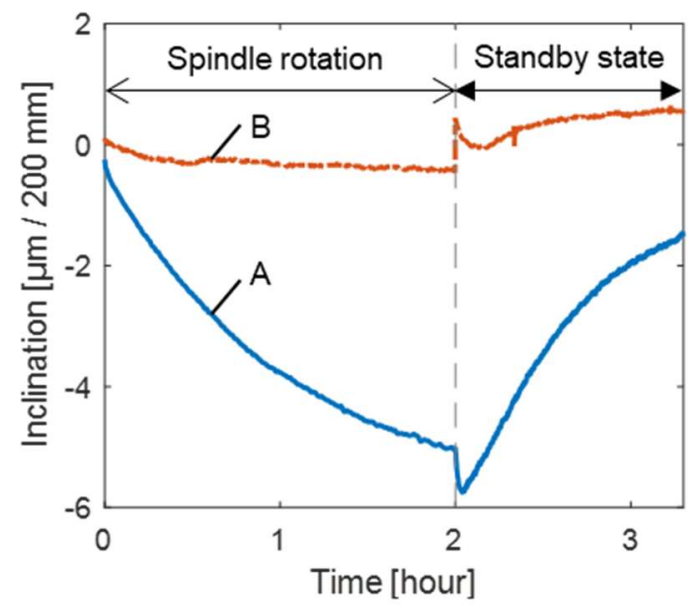

(a) Base machine

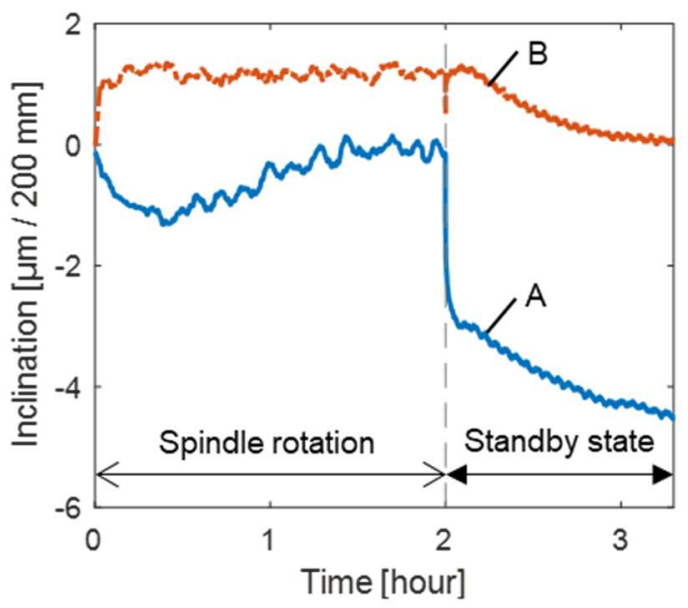

(b) Prototype machine

Fig. 8 Experimental results of inclination on spindle rotation in standby state.

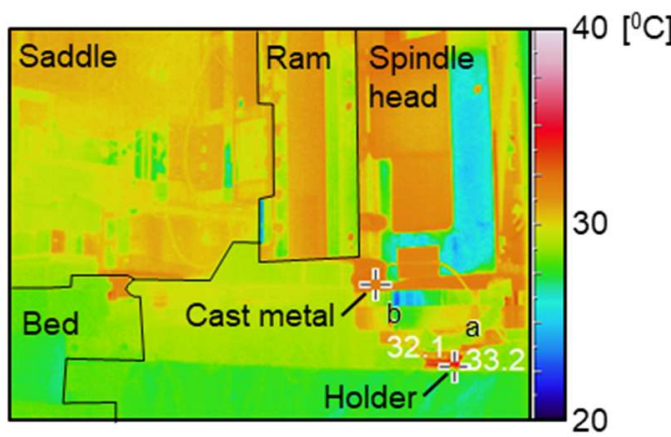

(a) Infrared image after stopping

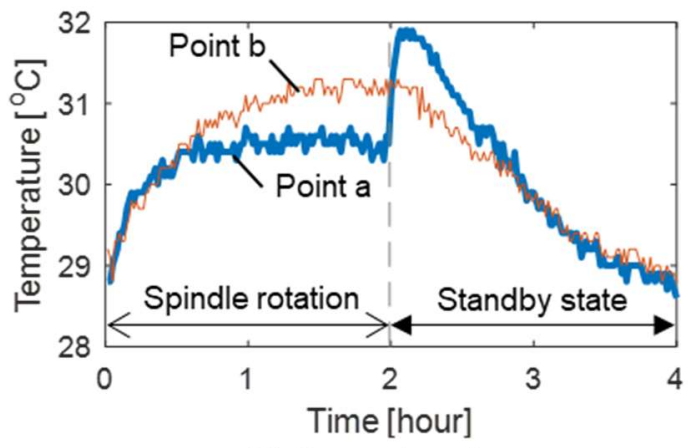

(b) Temperature change

Fig. 9 Temperature change around main spindle in standby state. 
Kato, Daisuke Kono, Yoshioka, Sugita, Hamaguchi, Kazumasa Kono, Iijima and Kakinuma, Transactions of the JSME (in Japanese), Vol.86, No.884 (2020)

が 1.5 度程度にとどまり，ベース機と比較して主軸端への熱伝導性が低い. 図 9 にはサーモグラフィで撮影した 赤外線画像と，主軸頭を覆う鋳物とホルダの温度変化を示寸. 図 9(b)に示寸 Point a における温度から, 主軸先端 に取り付けられているホルダは図 7(b) と同様に停止後 3 分で温度が上昇した後, 主軸を覆う鋳物以上の温度とな る. ベース機と開発機での主軸モータの発熱量は同様であるため, 開発機では主軸頭下部からの放熱がされにく い特性があるといえる．主軸停止時には対流による放熱量が低下寸ることで，主軸シャフト下部や八ウジングへ 回転時よりもより多くの熱伝導が行われ，主軸頭全体が傾き続けたと考えられる．開発機におけるこの熱変形の 挙動は今後の調査によって明らかにする予定である.

以上の結果より，CFRP を適用した開発機はざース機と比べ，熱変位が大幅に抑制されることを確認した。ま た，CFRP を適用した開発機の主軸頭はアイドリングストップ時に熱を保持する機能を持ち，工具-工作物間の相 対変位を維持する可能性を示した。しかし，駆動によって主軸頭が反り続ける傾向が見られ，この影響を評価す る必要がある.

\section{3. 暖機運転時間の短縮による省エネルギー加エの提案}

\section{$3 \cdot 1$ 暖機運転時間の最小化手法}

機械加工において，単一製品の量産を除いて，基本的に工作物に応じて工具の位置出しを含む段取り工程をそ の都度行う必要がある.したがって，段取り工程中の熱変位は問題になりにくく，加工中に生じる熱分布の変化 によって生じる熱変位が形状精度に影響する，高精度加工を達成するためには，熱変位推定による加工中の補正 は好ましくなく，加工中に熱変形が生じにくい機械設計を行うことが求められる．機械によらずに一般的な手法 として用いられている暖機運転は，加工開始以降の熱変位増加分が許容する誤差範囲内となるように，熱的な定 常状態を得るために行われている，暖機運転は通常工作機械起動後に行うものであり，一度暖機運転を行えば工 作機械の電源を落とすまで暖機運転を行わない，加工を続けて行う場合に待機時間が設けられれば放熱されて再 び過渡的な熱変形が生じるが，加工精度の継続的な補償を行うための適切な暖機運転時間について議論された例 は少ない，そこで加工精度を維持することを目的として，加工毎に毎回暖機運転を行い，その暖機運転時間を最 小化するモデルを提案する.

図 10 は加工終了時に生じる熱変位の一例を示寸. $E_{i}(t)[\mu \mathrm{m}]$ はワーク座標系と主軸座標系間に生じた実際の熱

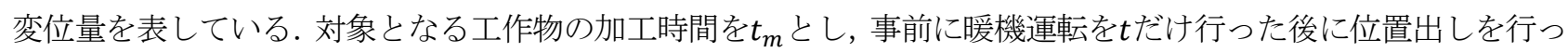
た場合の，加工終了時に主軸座標系から見たワーク座標系に生じる熱変位 $\Delta E_{i}[\mu \mathrm{m}]$ は以下のように表せる.

$$
\Delta E_{i}(t)=E_{i}\left(t_{m}+t\right)-E_{i}(t)
$$

目標とする加工精度を $\pm D[\mu \mathrm{m}]$ すると, $\left|\Delta E_{i}(0)\right|>D$ のときに加工中の誤差が目標值を超えてしまうため,

$$
\text { minimize: } S=\left(\left|\Delta E_{i}(t)\right|-D\right)^{2}
$$

の最小化問題を各軸方向で解くことで, 必要最低限の暖機運転時間 $t_{w}$ を算出する.

暖機運転時間は加工前に見積もる必要があり，熱変位推定值 $L_{i}(t)[\mu \mathrm{m}]$ を実際の熱変位量として用いることが 望まれる．これまで様々な推定手法が提案されているが，機体差を考慮した十分なサンプル数を確保することは コストがかかり，工場で運用した場合は温度環境の変化が大きく複雑であるため正確な推定は難しいことが知ら れている(千田他, 2004). そこで本研究では基本的な熱変位の推定手法として一次遅れ系へのモデル化を行い，モ デル化誤差 $\Delta L_{i}$ を考慮して, 加工のバラツキを許容するための係数 $\alpha$ を用いて加工精度維持に十分な暖機運転時間 を見積もる。

$$
\left|E_{i}\right|=\left|L_{i}+\Delta L_{i}\right|<\left|\alpha_{i} \times L_{i}\right|
$$


Kato, Daisuke Kono, Yoshioka, Sugita, Hamaguchi, Kazumasa Kono, Iijima and Kakinuma, Transactions of the JSME (in Japanese), Vol.86, No.884 (2020)

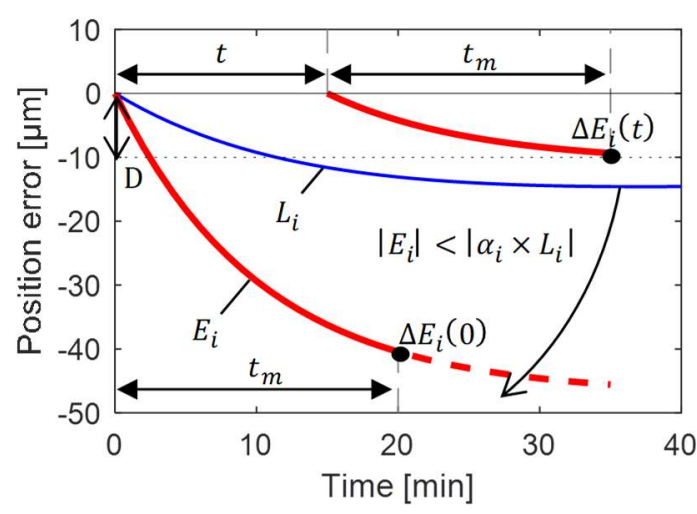

Fig. 10 Strategy of warm up time estimation depending on machining time and accuracy.

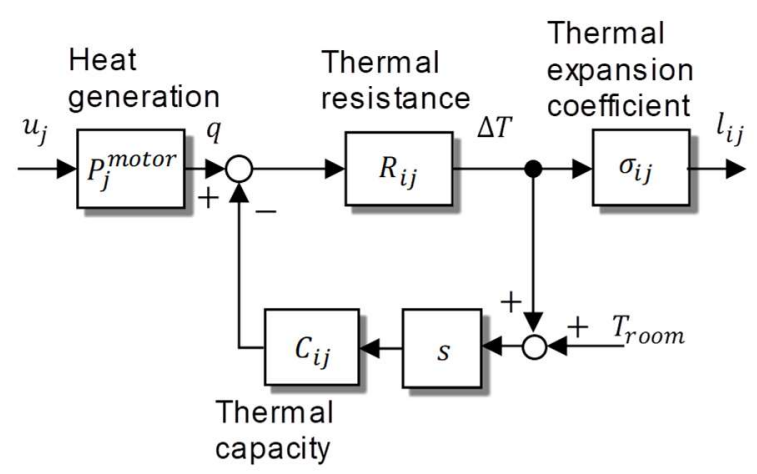

Fig. 11 Schematic block diagram of thermal error estimation.

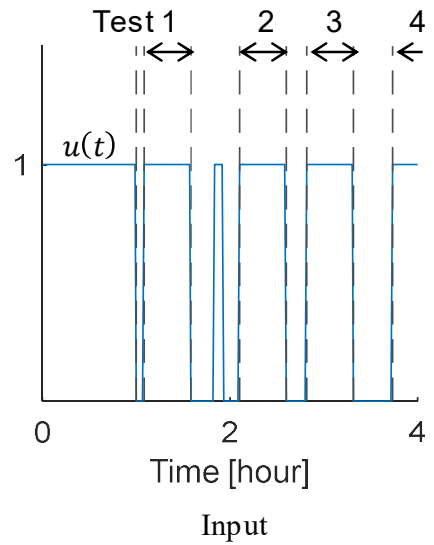

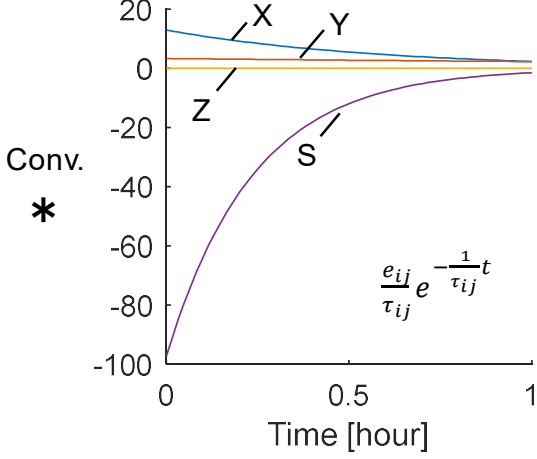

Time deviation of thermal error

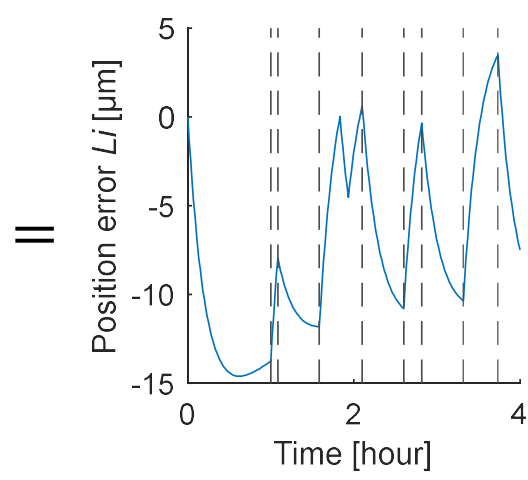

Output

Fig. 12 Estimation curve on base machine.

ここで，iは座標軸を表す．図 11 はある駆動軸 への指令 $u_{j}$ [-]: $(1 / 0)$ にって $i$ 軸方向に生じる熱変位までのブロ ック線図を示す． 3 軸の加工動作の場合では X, Y, Z 軸送りと主軸回転動作の 4 つが熱変位の主な要因として, モータの駆動によってそれぞれが独立して熱変位を発生させると仮定すると，式(4)より加工時間に応じた熱変位 を推定することができる.

$$
L_{i}(t)=\sum l_{i j}(t)=\sum_{j=1}^{4} \int_{0}^{t} \frac{e_{i j}}{\tau_{i j}} \exp \left(-\frac{1}{\tau_{i j}} \mathrm{~T}\right) u(t-\mathrm{T}) d \mathrm{~T}
$$

前章の熱変位測定の結果から最小二乗法により曲線近似を行い，定常熱変位である係数 $e_{i j}[\mu \mathrm{m}]$ と時定数 $\tau_{i j}$ [hour]を同定した結果を以下に示す．また図 12 には，この結果より推定した Z 軸方向の熱変位の時間応答を示し ている．前章では示していないが，X，Y 軸の送り動作でも Z 軸と同様に熱変位の測定を行っており，駆動に起 因したX 軸方向の熱変位は小さいため無視できるものとした.

$$
\begin{aligned}
\boldsymbol{e}^{\text {base }} & =\left[\begin{array}{llll}
e_{Y X} & e_{Y Y} & e_{Y Z} & e_{Y S} \\
e_{Z X} & e_{Z Y} & e_{Z Z} & e_{Z S}
\end{array}\right]=\left[\begin{array}{cccc}
2.6791 & -9.9090 & -15.0850 & -19.0390 \\
7.6296 & 8.9731 & 0 & -23.1420
\end{array}\right] \\
\boldsymbol{\tau}^{\text {base }} & =\left[\begin{array}{lllll}
\tau_{Y X} & \tau_{Y Y} & \tau_{Y Z} & \tau_{Y S} \\
\tau_{Z X} & \tau_{Z Y} & \tau_{Z Z} & \tau_{Z S}
\end{array}\right]=\left[\begin{array}{llll}
1.6870 & 3.7498 & 1.0545 & 1.4662 \\
0.5874 & 2.6608 & 0 & 0.2378
\end{array}\right]
\end{aligned}
$$


Kato, Daisuke Kono, Yoshioka, Sugita, Hamaguchi, Kazumasa Kono, Iijima and Kakinuma, Transactions of the JSME (in Japanese), Vol.86, No.884 (2020)

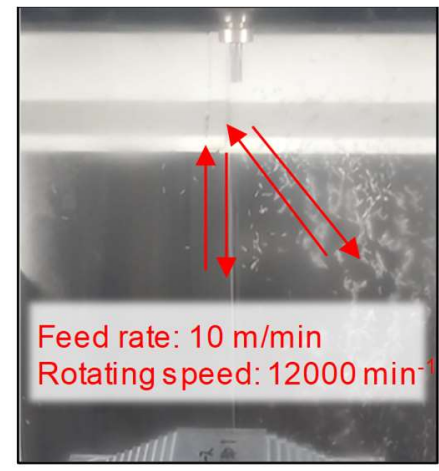

(a) Tool change

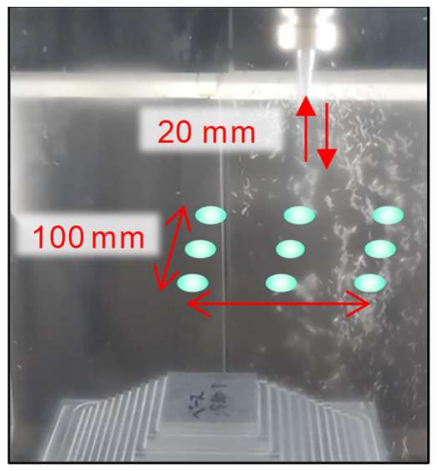

(b) Drilling 9 holes

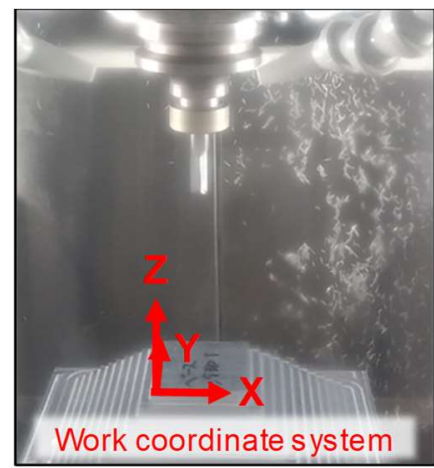

(c) Positioning for $10 \mathrm{sec}$

Fig. 13 One cycle behavior of warm up drive for approximately 20 secs, assuming drilling process.

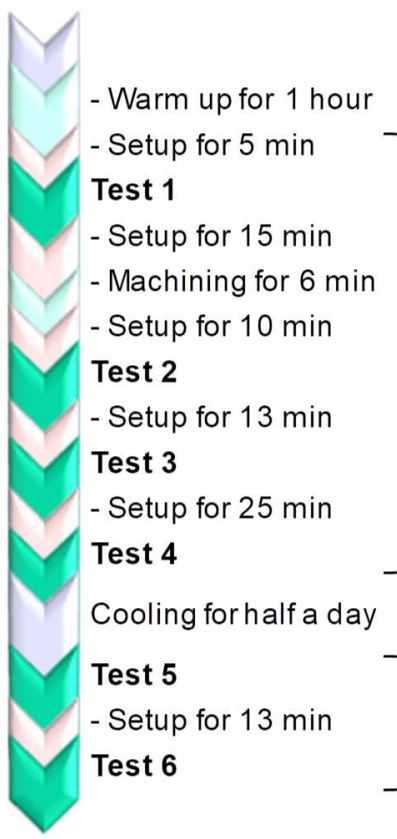

Fig. 14 Experimental conditions of machining test.
Machining after warm up drive. Test 1 assumes a condition in automated factories.

Test 2 and Test 3 assume actual setup by operators.

Test 4 assumes that machine tools have to wait for other process.

Machining without warm up drive (cold start).

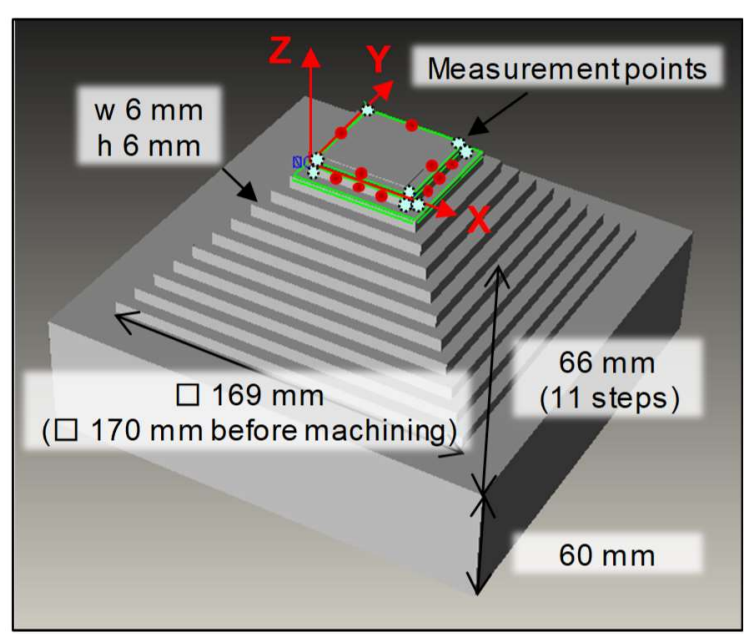

Fig. 15 Dimensions and measurement points of a test piece.

$$
\begin{aligned}
\boldsymbol{e}^{\text {proto }} & =\left[\begin{array}{llll}
e_{Y X} & e_{Y Y} & e_{Y Z} & e_{Y S} \\
e_{Z X} & e_{Z Y} & e_{Z Z} & e_{Z S}
\end{array}\right]=\left[\begin{array}{cccc}
8.0630 & -30.4230 & -23.8710 & -10.1590 \\
6.3867 & 9.5944 & 0 & -16.8690
\end{array}\right] \\
\boldsymbol{\tau}^{\text {proto }} & =\left[\begin{array}{llll}
\tau_{Y X} & \tau_{Y Y} & \tau_{Y Z} & \tau_{Y S} \\
\tau_{Z X} & \tau_{Z Y} & \tau_{Z Z} & \tau_{Z S}
\end{array}\right]=\left[\begin{array}{cccc}
4.8214 & 6.5398 & 4.6228 & 1.8168 \\
0.5157 & 4.2992 & 0 & 0.3233
\end{array}\right]
\end{aligned}
$$

\section{$3 \cdot 2$ 加工動作中の熱変位評価のための加工試験と形状精度の測定方法}

加工試験では，同じ加工動作を非等間隔な待機時間を設けて連続して行った場合に，どのように熱変位が生じ るかを評価した. 図 13 には本研究で設定した加工動作を示しており，工具交換を想定した駆動を含む穴あけ加工 を対象とした 1 サイクル 20 秒程度の運転である. 図 14 に実験条件となる加工前の暖機運転と待機時間を示す. モデルケースとして，1 時間の暖機運転後に 4 回と暖機運転を行わずに 2 回の加工を想定し, 合計 6 回のテスト を続けて行った。このテスト 1 6 では穴あけ加工動作（図 13）を約 30 分間繰り返すことで，工作機械に加工動 作による熱変形を与えた. 加工動作中の熱変位を直接測定することは難しいため, 図 15 に示寸ピラミッド状のテ ストピースを加工することで記録を行った．高さ $66 \mathrm{~mm}$ ，最上段の幅 $50 \mathrm{~mm}$ ，最下段の幅 $170 \mathrm{~mm}$ であり，幅 6 $\mathrm{mm}$ の各段を $0.5 \mathrm{~mm}$ 切り込むことでテストピース形状に工具-工作物間の熱変位を反映させる. 図 16 に加工試験 装置図と，テストピースの加工のフローチャートを示す．各テストでは，始めに上部 1 段目の加工を行うことで 


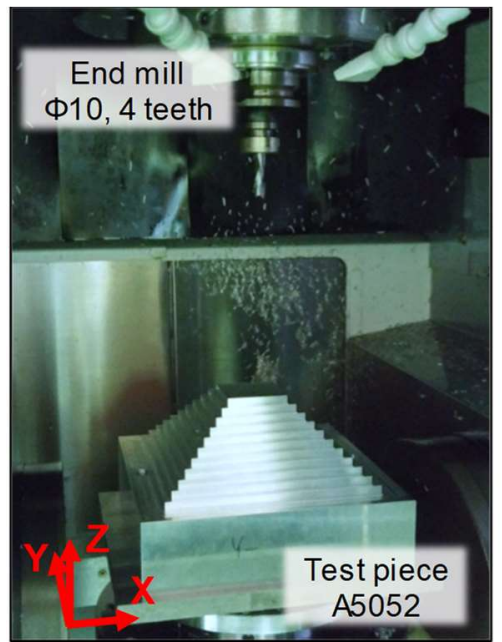

(a) Machining test on base machine

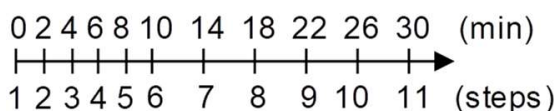

(b) Time scale for evaluation

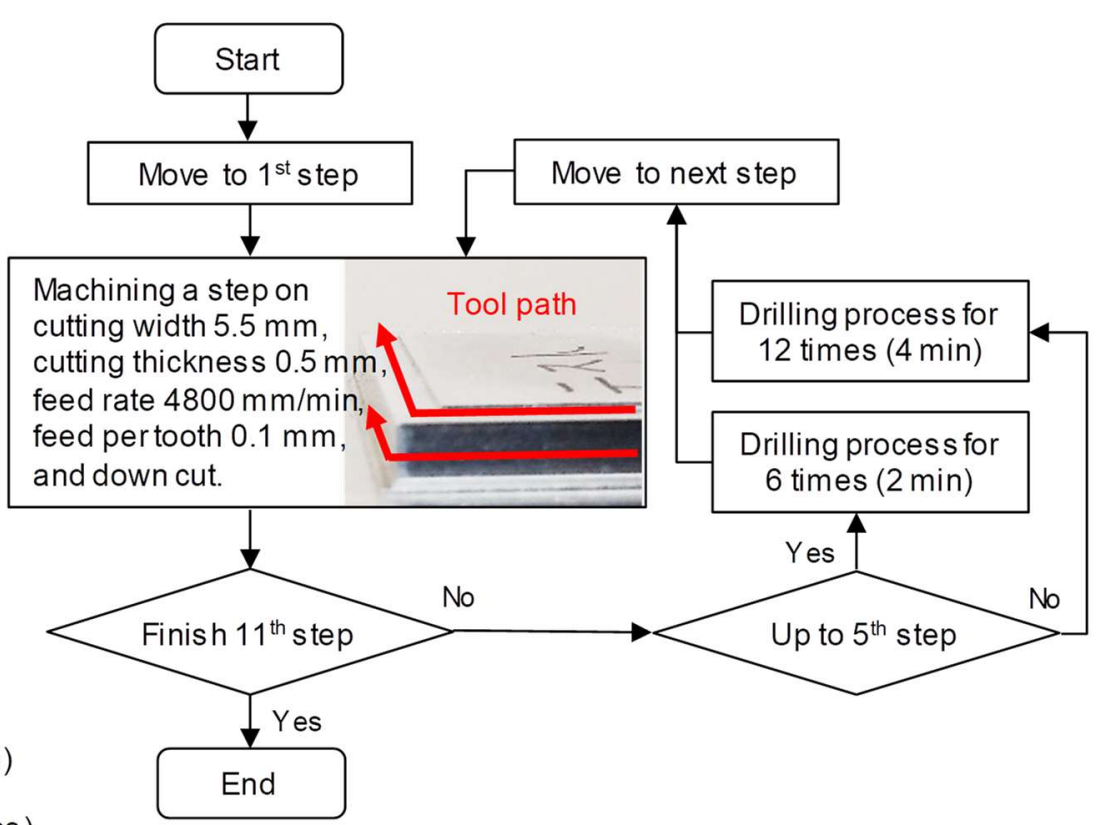

(c) Flowchart of machining a test piece

Fig. 16 Experimental setup for form accuracy evaluation.

ワーク座標系の基準面を記録する，その後，穴あけ加工動作（図 13）を繰り返した．この加工動作で生じる位置 出し時からの相対的な熱変位を記録するため，一定時間毎に基準面の加工と同じ加工方法で 1 つ下段の加工を 行う. 合計 11 段の加工（約 30 分）を，6段目の加工が終わるまで（約 10 分）は 2 分間隔，以降 11 段目まで（約 20 分）は 4 分間隔で繰り返し加工寸る. 記録のための加工は, テストピース各段の上面と側面を分けて行う.

テスト中に熱変位が生じている場合，加工プログラムを用いて作製したテストピースの寸法は CAD モデルの 理想的な寸法と異なる.このテストピースに生じた幾何誤差の測定は, CNC 三次元測定機 (CRYSTA-Apex S 700, Mitutoyo）で行った．茨木らはプローブ測定からワークの形状精度を測定する手法を提案している(Ibaraki et al., 2013). 幾何誤差が生じている工作機械で加工したワーク上の加工点 $\widehat{\boldsymbol{p}}(\boldsymbol{k})$ は，測定時の指令点 $\boldsymbol{p}^{*}(\boldsymbol{k})$ に同次変換行 列Dを用いて以下のように表される.

$$
\begin{aligned}
& {\left[\begin{array}{c}
\hat{\boldsymbol{p}}(k) \\
1
\end{array}\right]=\boldsymbol{D}_{\boldsymbol{x}}(\Delta x) \boldsymbol{D}_{\boldsymbol{y}}(\Delta y) \boldsymbol{D}_{\mathbf{z}}(\Delta z) \boldsymbol{D}_{\boldsymbol{a}}(\Delta \alpha) \boldsymbol{D}_{\boldsymbol{b}}(\Delta \beta) \boldsymbol{D}_{\boldsymbol{c}}(\Delta \gamma)\left[\begin{array}{c}
\boldsymbol{p}^{*}(k) \\
1
\end{array}\right]} \\
& \boldsymbol{D}_{\boldsymbol{x}}(\Delta x) \boldsymbol{D}_{\boldsymbol{y}}(\Delta y) \boldsymbol{D}_{z}(\Delta z) \boldsymbol{D}_{\boldsymbol{a}}(\Delta \alpha) \boldsymbol{D}_{\boldsymbol{b}}(\Delta \beta) \boldsymbol{D}_{\boldsymbol{c}}(\Delta \gamma) \approx\left[\begin{array}{cccc}
1 & -\Delta c & \Delta b & \Delta x \\
\Delta c & 1 & -\Delta a & \Delta y \\
-\Delta b & \Delta a & 1 & \Delta z \\
0 & 0 & 0 & 1
\end{array}\right]
\end{aligned}
$$

ここで，ワークに生じた位置誤差を $(\Delta x, \Delta y, \Delta z), \mathrm{X}, \mathrm{Y}, \mathrm{Z}$ 軸周りの傾きの誤差を $(\Delta a, \Delta b, \Delta c)$ とした. 工作機械に 生じた熱変位はテストピース上 1 段の加工を終えるまでに変化しないものとする. テストピース上 1 段を $\mathrm{N}$ 点プ ローブで測定した位置情報市 $(k)$ は，加工面に対して法線方向の変位のみを測定することができている．正規化さ れた面の法線ベクトル $\boldsymbol{n}^{*}(k)$ を用いて, 以下の最小問題を解くことで誤差が得られる.

$$
\text { minimize: } S=\sum_{k=1}^{N}\left\{(\overline{\boldsymbol{p}}(k)-\widehat{\boldsymbol{p}}(k)) \cdot \boldsymbol{n}^{*}(k)\right\}^{2}
$$


Kato, Daisuke Kono, Yoshioka, Sugita, Hamaguchi, Kazumasa Kono, Iijima and Kakinuma,

Transactions of the JSME (in Japanese), Vol.86, No.884 (2020)

測定点は図 15 に示すように，各段の上面は 8 点，側面は各 5 点ずつ辺から $1 \mathrm{~mm}$ 内側を等間隔になるよう定め た．そして，測定の際には 1 段目でワーク座標を定義し，テストピースの幾何誤差の同定には各段で四隅を除い た合計 16 点を用いた. 同定した誤差を, 1 段目を基準として熱で変化した実際の熱変位量 $\boldsymbol{E}_{\boldsymbol{i}}(\boldsymbol{t})$ として評価する.

\section{$3 \cdot 3$ 工作物の形状精度に基づく省エネルギ一性能評価}

図 17 にはベース機，図 18 には開発機の熱変位推定值と加工試験の結果を示す。測定結果は加工開始時間で原 点をとり, 段を加工した時間毎にプロットした。熱変位推定值は実線で, 加工試験の結果は一次遅れ系に近似し て破線で示した. テスト 2 では，3段加工した後に再び1段目で位置出しを行って試験をやり直したため，4段目 以降である 6 分後から測定結果をプロットしている. 加工試験中の室温はテスト 1 開始時 26.7 度，テスト 4 開 始時 27.0 度, テスト 5 開始時 25.8 度であった.

加工中の熱変位は, 暖機運転を行わないテスト 5 で最大となり, 30 分の駆動で生じた Z 軸方向の熱変位はベー ス機で $45.9 \mu \mathrm{m}$ ，開発機で $29.0 \mu \mathrm{m}$ と大幅に抑制されている. ベース機での Y 軸方向の熱変位はZ 軸方向の熱変 位と比べて小さく，概袝推定值と一致した．テスト 5 の後に 13 分の段取り時間を設けたテスト 6 の実験ではベ ース機で生じた Z 軸方向の熱変位は $25.6 \mu \mathrm{m}$ となり, 暖機運転を行ったテスト 1 からテスト 4 でも 15 25 $\mu \mathrm{m}$ の

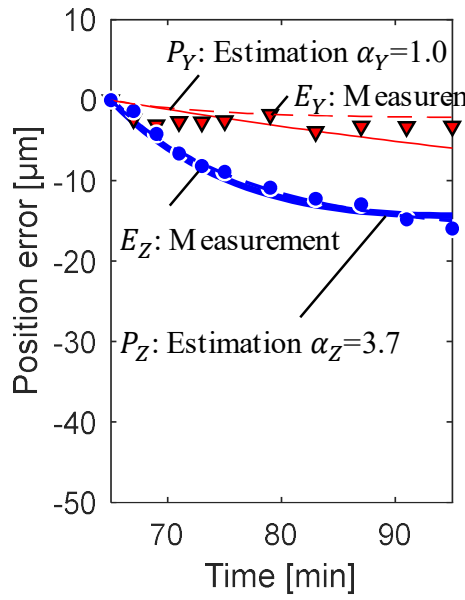

(a) Test 1: Warm up 1 hour and setup $5 \mathrm{~min}$

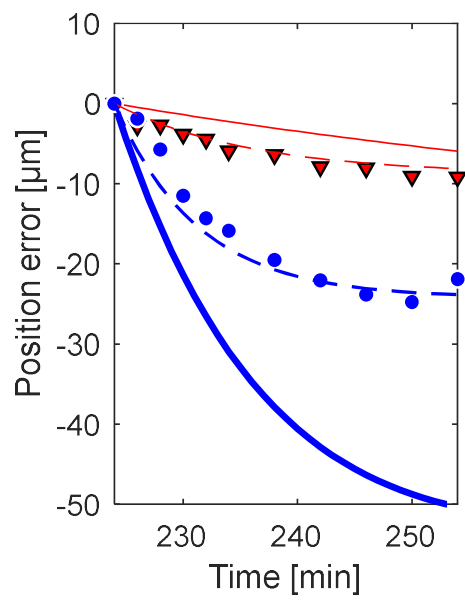

(d) Test 4: Setup $25 \mathrm{~min}$

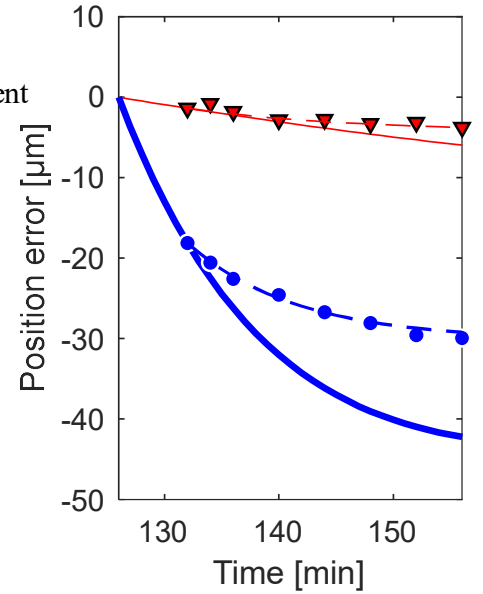

(b) Test 2: Setup 15 min, machining $6 \mathrm{~min}$ and setup $10 \mathrm{~min}$

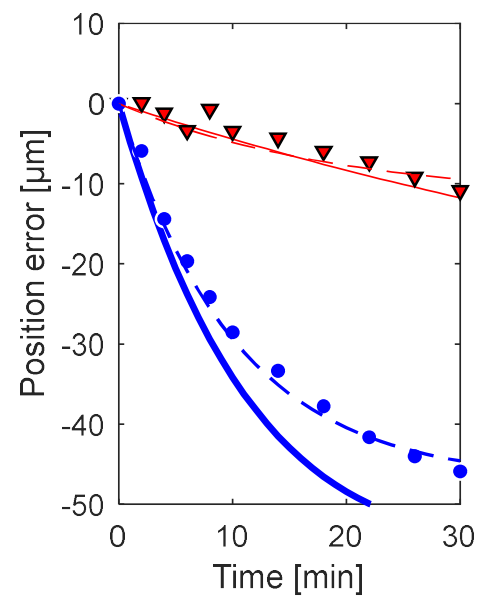

(e) Test 5: Cold start

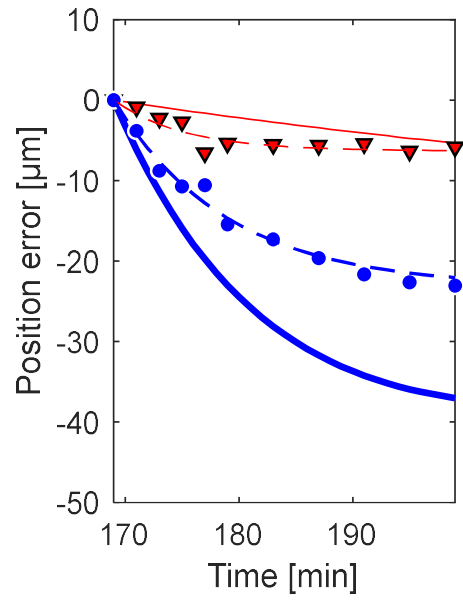

(c) Test 3: Setup $13 \mathrm{~min}$

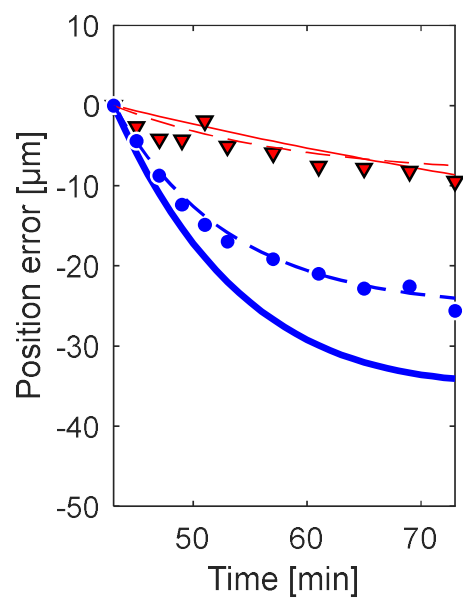

(f) Test 6: Setup $13 \mathrm{~min}$

Fig. 17 Thermal error on base machine.

Thermal error on Z-axis coordinate is observed $45.9 \mu \mathrm{m}$, in machining $30 \mathrm{~min}$ on test 5 . Thermal error changes at every test because of its large thermal expansion coefficient and its short time constant of thermal error. The coefficient of modeling error requires 3.7, based on the results on test 1 . The estimation curve on Y-axis coordinate shows good responses through all tests. 


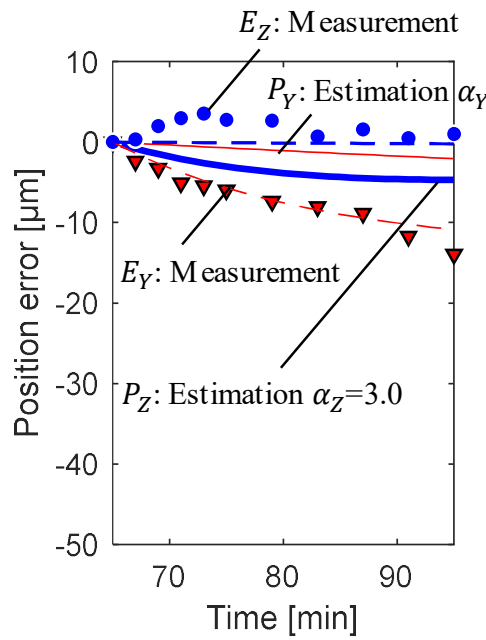

(a) Test 1: Warm up 1 hour and setup $5 \mathrm{~min}$

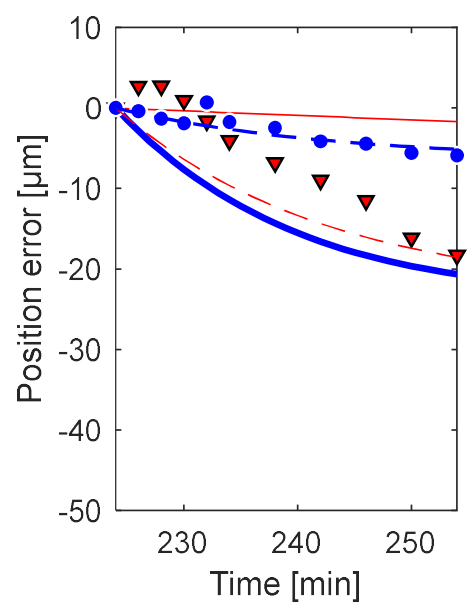

(d) Test 4: Setup $25 \mathrm{~min}$

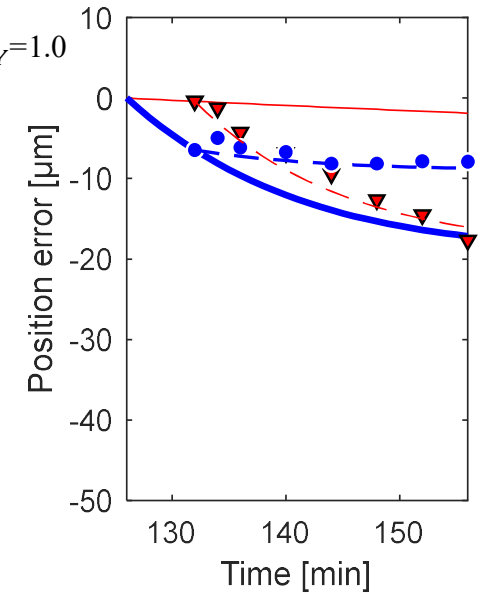

(b) Test 2: Setup 15 min, machining $6 \mathrm{~min}$ and setup $10 \mathrm{~min}$

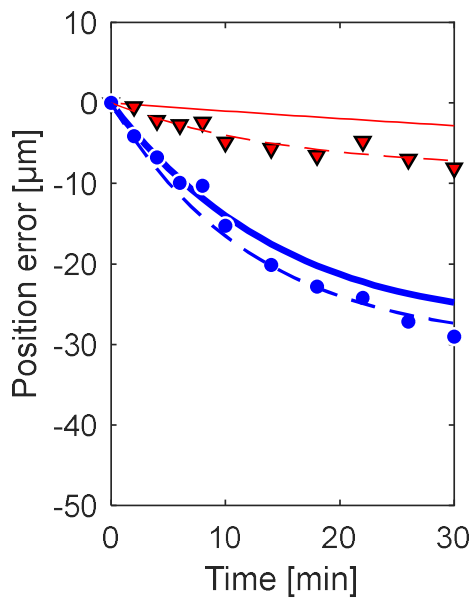

(e) Test 5: Cold start

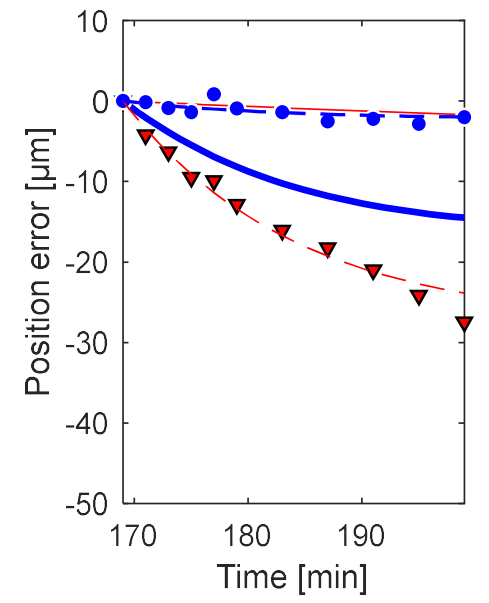

(c) Test 3: Setup $13 \mathrm{~min}$

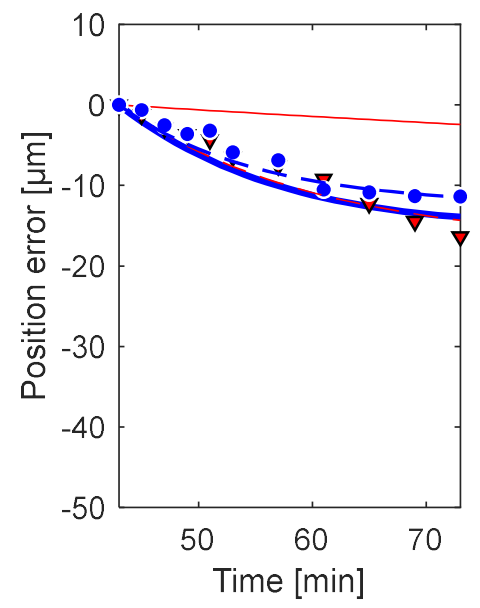

(f) Test 6: Setup $13 \mathrm{~min}$

Fig. 18 Thermal error on prototype machine.

Thermal error on Z-axis coordinate is obviously suppressed to $29.0 \mu \mathrm{m}$, in machining $30 \mathrm{~min}$ on test 5 . Thermal error does not dramatically change in comparison with base machine. The coefficient of modeling error requires 3.0, based on the results on test 5. The estimation curve on Y-axis coordinate does not work because of the inclination of its main spindle.

変位が確認された。一方開発機では, テスト 6 での加工中の熱変位は $11.3 \mu \mathrm{m}$ に留まり, 暖機運転を行ったテス ト 1 からテスト 4 では 30 分の加工で生じる熱変位が $5 \mu \mathrm{m}$ 以下となった．これは CFRP の生じる変位量が小さい だけでなく，時定数が長いことからも断熱性が高い材料であるために暖機運転で発生した熱が逃げにくいことが 起因している. 最長で 25 分の待機時間を設けた今回のモデルケースでは, Z 軸方向の変位に着目すれば十分に安 定した状態で加工を続けることができると言える.

しかし開発機の Y 軸方向の変位については, 暖機運転を行わなかったテスト 5 を除いて, 線形の熱変位が生じ ている．そこで図 19 には 2 時間以上運転をしたテスト 2 からテスト 4 の測定結果を加工した段を横軸にとって 示す. 最小二乗法により直線近似を行うと, 共通の傾きが生じていることがわかり, 平均して -0.076 degree と なった．これよりテストバーでの測定結果と同様に，主軸の発熱がハウジング側へ逃げたことで主軸頭が傾き， 熱変形による系統的誤差が生じたことが確認された.

そして図 17，18 の測定結果と式(2)より, 加工時間 $t_{m}$ を $20 \mathrm{~min}$, 目標の加工精度 $D$ を $10 \mu \mathrm{m}$ と設定して, 加工 精度維持に最低限必要な暖機運転時間 $t_{w}$ を算出した。表 5 に各テストの暖機運転時間を示す。また暖機運転時間

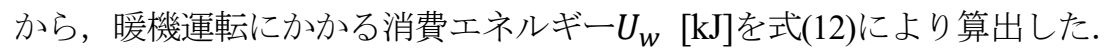


Kato, Daisuke Kono, Yoshioka, Sugita, Hamaguchi, Kazumasa Kono, Iijima and Kakinuma, Transactions of the JSME (in Japanese), Vol.86, No.884 (2020)

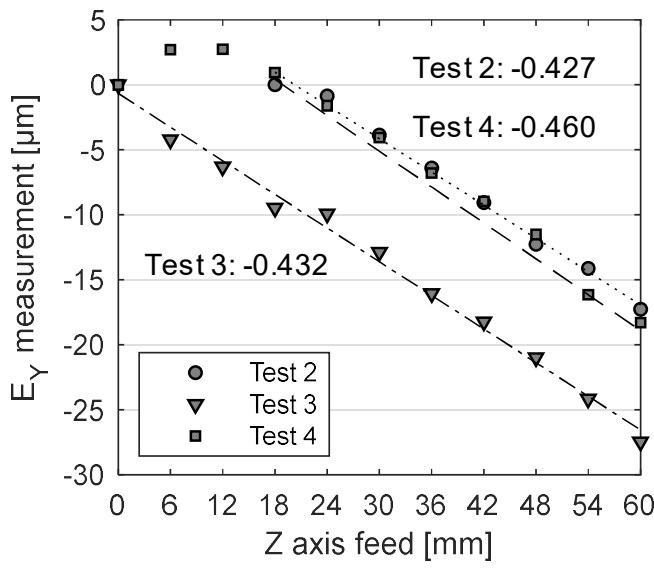

Fig. 19 Y axis geometric error on prototype machine.
Table 5 Minimized operation time and energy consumption of warm up drive.

\begin{tabular}{|c|c|c|c|c|c|c|}
\hline \multirow{3}{*}{ Test } & \multicolumn{3}{|c|}{ Base machine } & \multicolumn{3}{|c|}{ Prototype machine } \\
\hline & \multicolumn{2}{|c|}{$t_{w}[\mathrm{~min}]$} & \multirow{2}{*}{$\begin{array}{c}U_{w} \\
{[\mathrm{~kJ}]}\end{array}$} & \multicolumn{2}{|c|}{$t_{w}[\mathrm{~min}]$} & \multirow{2}{*}{$\begin{array}{c}U_{w} \\
{[\mathrm{~kJ}]}\end{array}$} \\
\hline & Y-axis & $Z$-axis & & Y-axis & Z-axis & \\
\hline 1 & 0 & 4 & 910 & 0 & 0 & 0 \\
\hline 2 & 0 & 7 & 1592 & 11 & 0 & 1832 \\
\hline 3 & 0 & 7 & 1592 & 11 & 0 & 1832 \\
\hline 4 & 0 & 6 & 1364 & 8 & 0 & 1332 \\
\hline 5 & 0 & 15 & 3411 & 0 & 12 & 1998 \\
\hline 6 & 0 & 8 & 1819 & 4 & 1 & 666 \\
\hline Total & \multicolumn{2}{|c|}{47} & 10688 & \multicolumn{2}{|c|}{46} & 7659 \\
\hline
\end{tabular}

$$
U_{w}=\left(P_{m}+P_{p}\right) \times t_{w}
$$

穴あけ加工動作の駆動にかかる電力 $P_{m}[\mathrm{~kW}$ を同定するため, CNC ガイド（SERVO GUIDE, FANUC）で 1 サイ クル（20 秒）の駆動にかかる消費エネルギーの測定を行った．消費エネルギーはベース機で $51.8 \mathrm{~kJ}$ ，軽量化の効

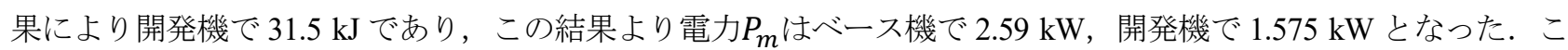
の他の周辺装置の消費電力 $P_{p}$ は公称值より $1.2 \mathrm{~kW}$ である. 暖機運転時間にこの消費電力の係数を乗じることで, 今回のモデルケースで 6つの加工を行う際に必要なエネルギーは $10688 \mathrm{~kJ}$ から $7659 \mathrm{~kJ}$ と $28.3 \%$ 削減可能となる. 主軸回転動作で発生する傾きの補正を行えば，長時間の運転での追加の暖機運転は不要となり，大幅なエネルギ 一削減が達成できると考えられる. 加えて, 開発機ではアイドリングストップ中に熱を保持し停止中の工具-工作 物間の変位が一定となる応答が得られたことから，暖機運転時間の更なる短縮につながるため，アイドリングス トップの導入を行うべきである.

また暖機運転時間を事前に見積もるために，テスト 1 からテスト 6 の加工すべてで精度維持が達成可能となる ような式(3)のモデル化誤差の決定を行った. 全てのテストで表 5 に示した必要最低限の暖機運転時間以上となる ような係数 $\alpha_{Z}$ の最小值は, ベース機で $\alpha_{Z}=3.7$, 開発機で $\alpha_{Z}=3.0$ となった. そして，式(4)の Z 軸方向の熱変位 推定值を用いた式(3)から，式(2)を用いて暖機運転時間を算出した。このときベース機での Z 軸変位が支配的であ るため, 必然的に Y 軸方向 $10 \mu \mathrm{m}$ の寸法精度維持に十分な暖機運転が行われる. また開発機の $\mathrm{Y}$ 軸方向の変位 は，A 軸ステージで補正することを前提としている。この推定值を用いて暖機運転時間を決定した場合，べース 機は $17965 \mathrm{~kJ}$ (75 min), 開発機では $7732 \mathrm{~kJ}$ (34 min)と 57.0\%少ない消費エネルギーで加工中の精度を保つことが 可能である. ベース機では放熱が早く加工毎にバラツキが大きく生じており，熱膨張率が大きいため変位量に大 きな変動が生じた。この結果モデル化誤差が大きくなるため暖機運転が長く必要となり，消費エネルギーの増分 が大きくなった．開発機では新構造材料を適用したことで，熱変位の変化が再現性の高い傾向を示した.

以上の結果から，新構造材料を適用した開発機では，モデルケースで想定した工作物と加工時間での加工で良 好な加工精度を保つことができるといえ，精度を保つための暖機運転時間の削減に貢献するままた，新型機の開 発においては機械的な設計技術だけでなく，冷却機構の最適化など熱的な観点での設計技術も求められる.

\section{4. 結言}

本研究では，新構造材料を適用した工作機械の熱変位の評価を行い，省エネルギ一性能を評価するための加工 試験を行った。そして，目標とする工作物の加工時間と加工精度を設定し，許容するモデル化誤差から暖機運転 時間を最小化する省エネルギ一加工の提案を行った．以下に本研究で得られた成果を，ベース機と開発機の比較 結果を基にまとめた。 
Kato, Daisuke Kono, Yoshioka, Sugita, Hamaguchi, Kazumasa Kono, Iijima and Kakinuma, Transactions of the JSME (in Japanese), Vol.86, No.884 (2020)

1. CFRP の適用により，同じ構造を持ったベース機と比べて開発機では主軸先端で生じる熱変位が低減するこ とを確認した. 3 時間の Z 軸送りの運転で生じる Y 軸方向の変位は $15.2 \mu \mathrm{m}$ から $10.6 \mu \mathrm{m}$ に 30.2\%減少し, 2 時間の主軸回転動作で生じる Y 軸方向の変位は $14.3 \mu \mathrm{m}$ から $6.3 \mu \mathrm{m}$ に 55.9\%減少，Z 軸方向の変位は 24.1 $\mu \mathrm{m}$ から $18.2 \mu \mathrm{m}$ に $24.5 \%$ 減少した。

2. 工作機械で泠却機構のアイドリングストップを行い，主軸先端で生じる熱変位を測定した。CFRP を適用し た主軸で温度を保持する応答が得られ，Z 軸方向の熱変位は 1 時間以上一定值を保った．エネルギーの観点 に加えて精度の観点からも, 熱的な機械設計の最適化とアイドリングストップの導入を今後進めていくべき である.

3. 加工試験では同じ加工動作を繰り返すことで，事前の暖機運転の有無と非等間隔な待機時間が熱変位の時間 変化に与える影響を評価した。暖機運転を行わないコールドスタートで 30 分間の加工を行った場合， Z 軸 方向の加工誤差は $36.8 \%$ 抑制された。 開発機では加工中の熱変位が小さいことに加え，熱変位の時間変化が 緩やかであることから，暖機運転を行った場合でも高精度で加工を続けることが可能となる.

4. 加工試験の結果より，20 分間の加工で形状精度 $10 \mu \mathrm{m}$ を達成するための暖機運転時間を算出した. 6 回の加 工を行った今回のモデルケースでは，最低限必要な暖機運転時間の合計を 47 分から 29 分に短縮可能で，暖 機運転中の消費エネルギーを $10688 \mathrm{~kJ}$ から $7659 \mathrm{~kJ}$ と 28.3\%削減可能であることを示した．また，熱変位モ デルを用いて事前決定した暖機運転時間の合計は，75 分から 34 分となり，必要な消費エネルギーを 17965 $\mathrm{kJ}$ から $7732 \mathrm{~kJ}$ と $57.0 \%$ 削減できることを示した.

\section{謝 辞}

この成果は，国立研究開発法人新エネルギー・産業技術総合開発機構（NEDO）戦略的省エネルギー革新プロ グラム助成事業の結果得られた．本プロジェクトに参加した，DMG 森精機（株），(株）ジェイテクト，三井精 機工業（株），中村留精密工業（株），OKK（株），ヤマザキマザック（株）の各社に謝意を示す．

\section{文献}

Altıntaş, R. S., Kahya, M. and Ünver, H. Ö., Modelling and optimization of energy consumption for feature based milling, International Journal of Advanced Manufacturing Technology, Vol. 86 (2016), pp.3345-3363.

Fujishima, M., Shimanoe, H. and Mori, M., Reducing the energy consumption of machine tools, International Journal of Automation Technology, Vol. 11, No. 4 (2017), pp.601-607.

Ibaraki, S., Iritani, T. and Matsushita, T., Error map construction for rotary axes on five-axis machine tools by on-the-machine measurement using a touch-trigger probe, International Journal of Machine Tools \& Manufacture, Vol. 68 (2013), pp.2129.

加藤潤, 吉岡勇人, 新野秀憲, 朝倉和廣, 後藤俊輔, 臼田敬介, 堀伸充, CFRP を適用した熱変形抑制ボールねじ の性能評価，2018 年度精密工学会秋季大会, B01-4 (2018), pp.145-146.

Kono, D., Mizuno, S., Muraki, T. and Nakaminami, M., A machine tool motorized spindle with hybrid structure of steel and carbon fiber composite, CIRP Annals, Vol. 68, Issue 1 (2019), pp.389-392.

Lee, W., Kim, S. H., Park, J. and Min, B. K., Simulation-based machining condition optimization for machine tool energy consumption reduction, Journal of Cleaner Production, Vol. 150 (2017), pp.352-360.

Mayr, J., Jedrzejewski, J., Uhlmann, E., Donmez, M. A., Knapp, W., Härtig, F., Wendt, K., Moriwaki, T., Shore, P., Schmitt, R., Brecher, C., Würz, T. and Wegener, K., Thermal issues in machine tools, CIRP Annals, Vol. 61, Issue 2 (2012), pp.771791.

経済産業省資源エネルギー庁, 平成 29 年度エネルギーに関する年次報告, 第 196 回国会(常会), 平成 30 年 6 月 8 日 (2018), pp. 136-143.

Möhring, H. C., Brecher, C., Abele, E., Fleischer, J. and Bleicher, F., Materials in machine tool structures, CIRP Annals Vol.64, Issue 2 (2015), pp.725-748.

Ohtani, H., Development of energy-saving machine tool, International Journal of Automation Technology, Vol.11, No.4 (2017), pp.608-614. 
Regel, J., Xu, D., Bräunig, M., Wittstock, V. and Putz, M., Evaluation of thermo-energetic behavior for demand-oriented operating of machine tool cooling systems, Procedia Manufacturing, Vol. 21 (2018), pp.213-220.

千田治光，佐藤礼士，森脇俊道，量産を目的とした工作機械の主軸熱変位推定(第 1 報,主軸温度と主軸熱変位の関 係), 日本機械学会論文集 C 編, Vol.70, No.698 (2004), pp.2961-2965.

杉田直彦, 吉岡勇人, 柿沼康弘, 河野大輔, 新構造材料適用省工市型工作機械の研究開発, 精密工学会春季大会学 術講演会講演論文集(2019), pp.211-212.

Ullah, A. M. M. S., Akamatsu, T., Furuno, M., Chowdhury, M. A. K. and Kubo, A., Strategies for developing milling tools from the viewpoint of sustainable manufacturing, International Journal of Automation Technology, Vol. 10, No. 5 (2016), pp. 727-736.

Weber, J., Shabi, L. and Weber, J., State of the art and optimization of the energy flow in cooling systems of motorized highspeed spindles in machine tools, Procedia CIRP, Vol. 67 (2018), pp.81-86.

\section{References}

Altıntaş, R. S., Kahya, M. and Ünver, H. Ö., Modelling and optimization of energy consumption for feature based milling, International Journal of Advanced Manufacturing Technology, Vol. 86 (2016), pp.3345-3363.

Fujishima, M., Shimanoe, H. and Mori, M., Reducing the energy consumption of machine tools, International Journal of Automation Technology, Vol. 11, No. 4 (2017), pp.601-607.

Ibaraki, S., Iritani, T. and Matsushita, T., Error map construction for rotary axes on five-axis machine tools by on-the-machine measurement using a touch-trigger probe, International Journal of Machine Tools \& Manufacture, Vol. 68 (2013), pp.2129.

Kato, J., Yoshioka, H., Shinno, H., Asakura, K., Goto, S., Usuda, K. and Hori, N., CFRP wotekiyoushitanetuhenkeiyokuseiborunezinoseinouhyouka, The Japan Society for Precision Engineering Autumn Conference, B01-4 (2018), pp.145-146 (in Japanese).

Kono, D., Mizuno, S., Muraki, T. and Nakaminami, M., A machine tool motorized spindle with hybrid structure of steel and carbon fiber composite, CIRP Annals, Vol.68, Issue 1 (2019), pp.389-392.

Lee, W., Kim, S. H., Park, J. and Min, B. K., Simulation-based machining condition optimization for machine tool energy consumption reduction, Journal of Cleaner Production, Vol. 150 (2017), pp.352-360.

Mayr, J., Jedrzejewski, J., Uhlmann, E., Donmez, M. A., Knapp, W., Härtig, F., Wendt, K., Moriwaki, T., Shore, P., Schmitt, R., Brecher, C., Würz, T. and Wegener, K., Thermal issues in machine tools, CIRP Annals, Vol. 61, Issue 2 (2012), pp.771791.

Ministry of Economy Trade and Industry, The Cabinet Approve the FY 2017 Annual Report on Energy, Japan's Energy White Paper 2018 (2018), pp.136-143 (in Japanese).

Möhring, H. C., Brecher, C., Abele, E., Fleischer, J. and Bleicher, F., Materials in machine tool structures, CIRP Annals Vol.64, Issue 2 (2015), pp.725-748.

Ohtani, H., Development of energy-saving machine tool, International Journal of Automation Technology, Vol.11, No.4 (2017), pp.608-614.

Regel, J., Xu, D., Bräunig, M., Wittstock, V. and Putz, M., Evaluation of thermo-energetic behavior for demand-oriented operating of machine tool cooling systems, Procedia Manufacturing, Vol. 21 (2018), pp.213-220.

Senda, H., Sato, R. and Moriwaki, T., Estimation of thermal displacement of machine tool spindles for mass production (1st report, relation between temperature rise and thermal deformation of main spindle), Transactions of the Japan Society of Mechanical Engineers, Series C, Vol.70, No.698 (2004), pp.2961-2965 (in Japanese).

Sugita, N., Yoshioka, Y., Kakinuma, Y. and Kono, D., Shinkouzouzairyoutekiyou-syouenegatakousakukikai-nokenkyuukaihatu, The Japan Society for Precision Engineering Spring Conference (2019), pp.211-212 (in Japanese).

Ullah, A. M. M. S., Akamatsu, T., Furuno, M., Chowdhury, M. A. K. and Kubo, A., Strategies for developing milling tools from the viewpoint of sustainable manufacturing, International Journal of Automation Technology, Vol. 10, No. 5 (2016), pp. 727-736.

Weber, J., Shabi, L. and Weber, J., State of the art and optimization of the energy flow in cooling systems of motorized highspeed spindles in machine tools, Procedia CIRP, Vol. 67 (2018), pp.81-86. 